\title{
CONSIGNMENTS AND THE DRAFT COMMON FRAME OF REFERENCE
}

\begin{abstract}
One of the novelties of Book IX of the most recent achievement of European efforts aimed at harmonization of private laws, the Draft Common Frame of Reference, concerns the subjection of some types of consignments to secured transactions law. The paper endeavors to unearth, what main dilemmas are corollary to, and what factors may justify transplantation of a solution from a system based on 'functional approach' - Article 9 of the American Uniform Commercial Code - into a law predominantly still based on system thinking (legal dogmatism).
\end{abstract}

Key words: consignment, harmonization of European private law, Draft Common Frame of Reference, Uniform Commercial Code of the United States of America, consignment as a secured transaction, transplantation, function approach, legal dogmatism, behavioral economics, ostensible ownership (false wealth), purchase-money security interest, priorities, trust receipts, second generation of financiers.

\section{List of ABBREVIATIONS}

\begin{tabular}{|l|c|l|}
\hline CEE & - & Central and Eastern Europe \\
\hline DCFR & - & Draft Common Frame of Reference (EU) \\
\hline EBRD & - & European Bank for Reconstruction and Development (London, UK) \\
\hline EU & - & European Union \\
\hline ROT & - & Retained title (ownership) \\
\hline SEC & - & Securities and Exchange Commission (US) \\
\hline SME & - & Small and Mid-scale Enterprise \\
\hline
\end{tabular}

* Professor of Law, Central European University, Budapest, Hungary. Contact: tajtit@ ceu.hu. The author would like to express his thankfulness for their kind help to Professor Hans-Eric Rasmussen and student Patricia Živković and to Professor Stefan Messmann for his comments. 


\begin{tabular}{|l|c|l|}
\hline UCC & - & Uniform Commercial Code (US) \\
\hline UK & - & United Kingdom \\
\hline US & - & United States of America \\
\hline USAID & - & United States Agency for International Development \\
\hline
\end{tabular}

\section{Why This Topic?}

At least four reasons justify writing on the relationship of such conventional contracts as consignments and secured transactions law: ${ }^{1}$ one of the hottest legal reform areas of the last two decades. The first is that secured transactions law reforms are still ongoing in much of CEE and some western European systems have also taken steps to modernize their respective laws. This is of importance as according to the leading contemporary model enshrined into UCC Article 9 extends also to consignments. Talking of reforms in CEE, suffice to mention the reforms assisted by the EBRD (e.g., Hungary, ${ }^{2}$ Slovakia ${ }^{3}$ ), USAID (Romania) ${ }^{4}$ or Canadian

1 The designation 'secured transactions' law is used only in the US and is that separate branch of law which is regulated by UCC Article 9. Other common law systems' designation for it is 'personal property security law'. In Germany there is no compact branch of law, hence, the correct naming would be 'the law of credit securities' („Recht der Kreditsicherheiten"). In the post-Yugoslav countries the best description of the field would be „založno pravo“ though with (at least) two crucial distinctions: 1/ UCC Article 9 does not cover real property used as collateral; and 2/ UCC Article 9 extends also to such title financing transactions as 'financial' and other types of leasing, conditional sales or consignments because the system covers all transactions, irrespective how named, but which are used as securities.

2 Hungary has revamped its secured transactions law for the third time with the passing of the new Civil Code (Act CXX of 2009 on the Civil Code of the Republic of Hungary, passed on 20 November 2009, published in the Official Gazette No. 165/2009). The first, EBRD Model Law and through that the UCC Article 9-inspired amendments of the old Civil Code were made in 1996, what was followed by the launching of the registry for charges on movables (kept by public notaries) and a major amendment of the new rules in 2000. For the first two reforms see, e.g., Tibor Tajti, Comparative Secured Transactions Law (Akadémiai könyvkiadó, Budapest, 2002) and Tibor Tajti, Viehweg's Topics, Article 9 UCC, the „kautelarische Sicherheiten“ and the Hungarian Secured Transactions Law Reform, 6 Vindobona J. 93(1) (2002) (downloadable at <http:// www.SSRN.com>). On the latest changes see Norbert Csizmazia, Reform of the Hungarian Law on Security Rights in Moveable Property (<http://www.SSRN.com>).

3 Law Amending the Civil Code, Notarial Law and other Laws (2002) (as amended later).

4 Two acts should be mentioned, first the Government Ordinance No. 51/1997 - first act regulating 'leasing' in Romania - and the Law No. 99/1999 on Security Interests in Movable Property (as amended). See, e.g., Ileana M. Smeureanu, Good News from Ro- 
experts (Ukraine) ${ }^{5}$ or the countries of the West-Balkans joining the efforts with a bit of a delay. ${ }^{6}$ In the western European hemisphere, the French 2002 revamping of commercial laws should be in particular mentioned given that exactly the upgrading of secured transactions laws was one of the main impetuses behind the changes. ${ }^{7}$

Secondly, the latest product of European harmonization efforts, the DCFR $)^{8}$ has made a leap forward as far as the reconciliation of the often completely opposing concepts and policy choices of secured transactions laws are concerned: including the recognized need to bring consignments under the penumbras of secured transactions law. ${ }^{9}$ Notwithstanding that

mania: the Leasing Market is Expanding, in: Stefan Messmann \& Tibor Tajti, the Case Law of Central and Eastern Europe - Leasing, Piercing the Corporate Veil and the Liability of Managers \& Controlling Shareholders, Takeovers and the Problems with Collateral Laws (European University Press, 2007, Bochum, Germany), pp. 264-297.

5 See, e.g., Leonila Guglya \& Oleksiy Kononov, Enforcement of Contracts in Ukraine, in: Stefan Messmann \& Tibor Tajti, the Case Law of Central and Eastern Europe - Enforcement of Contracts (European University Press, 2009, Bochum, Germany) vol. II, section 5.2.1., pp. 1041-1048.

6 Let us mention Serbia and Croatia. Both of them treated leasing separately from security interests on movables. The Serbian acts are the Law on Registered Charges on Movable Assets (Official Gazette No. 57/2003) and the 2003 Law on Financial Leasing (first law introducing this novel transaction) - which has been replaced by a new act in 2011 (Official Gazette No. 31/2011 of 9 May 2011)). The registry of security interests - as well as a registry of financial leasing and bankruptcy estates - is kept by the Business Registers Agency („Agencija za Privredne Registre“) and could be consulted at $<$ http://www.apr.gov.rs/>. The texts of all relevant acts are available for downloading from this source, too.

The Croatian acts of relevance are the 2006 Law on Leasing, the 2005 Law on the Registry of Judicial and Public Notary Charges on Movables and Right (Official Gazette 121/05) - section 38 of which has introduced the concept of floating charge (or floating lien) for the first time to Croatia - and the Law on Property and other Proprietary Entitlements (inherited from the former Yugoslavia and as amended).

7 See Code de Commerce (2002), Title Four, Chapter Two - Charges on a Business. English translation of the code is available at <http://www.legifrance.gouv.fr/html/ codes_traduits/commercetextA.htm>.

8 The full title of the document is „Principles, Definitions and Model Rules of European Private Law - Draft Common Frame of Reference (DCFR)“ (Sellier.european law publishers $\mathrm{GmbH}$, Munich), the outline version of the text of which can be downloaded at $<$ http://ec.europa.eu/justice/policies/civil/docs/dcfr_outline_edition_en.pdf >; last visited 23 October 2011. The document was prepared by two European research groups, the Study Group on a European Civil Code $[<\mathrm{http}: / /$ www.sgecc.net/>] and the Research Group on the EC Private Law (Acquis Group) [<http://www.acquis-group.org/>].

9 As Anna Veneziano, member of the Study Group on a European Civil Code put forward - though without explaining the very reasons for the proposition - „[e]ven stronger is the need for common rules in the case of consignment contracts." See Anna Veneziano, A Secured Transactions' Regime for Europe: Treatment of Acquisition Finance Devices 
the DCFR is at the moment merely „a text serving as a source of inspiration for law making and law teaching at all levels" 10 and it is not clear what is going to be its fate, ${ }^{11}$ let alone the critical voices, ${ }^{12}$ it is an important development destined to affect the future of European commercial law. Book IX of the DCFR, entitled 'Proprietary Security in Movable Assets', indeed, now explicitly regulates consignments as one type of 'retention of ownership devices. ${ }^{13}$ Or, a transaction in which the creditor (supplier-consignor) gives certain goods into the possession of the debtor (consignee) and in which the main security device ensuring payment and performance by the debtor is the retained ownership (or retained title). Without intending to list all the consignment-related provisions, it is a crucial novelty that all security-consignments are subject to registration exactly as security interests on movables are. ${ }^{14}$ As it will be shown in this article, however, it is

and Creditor's (sic) Enforcement Rights, in Juridica International, XIV 2008, published by the University of Tartu, Estonia, pp. 89-95, available electronically at $<$ http://www. juridicainternational.eu/a-secured-transactions-regime-for-europe-treatment-of-acquisition-finance-devices-and-creditors-enforcement-rights>; last visited 23 October 2011.

10 Christian von Bar, A Common Frame of Reference for European Private Law - Academic Efforts and Political Realities, Electronic Journal of Comparative Law, at 1 (<www.ejcl.org/121/art121-27.pdf>).

11 See the Green Paper from the [European] Commission on policy options for progress towards a European Contract Law for consumers and businesses(Brussels, 1.7.2010, $\operatorname{COM}(2010) 348$ final), which foresees seven possible options for the DCFR, from being used only as a source of inspiration to lawmakers and a teaching tool through the option of transformation into a genuine European code.

12 On the history, nature and criticism of the DCFR see Reinhard Zimmermann, A European civil code in all but name, Cambridge Law Journal vol. 69(1) (2010), at 98112; Reinhard Zimmermann, The Present State of European Private Law, 57 American Journal of Comparative Law vol. 57 (2009), at 479, Luisa Antoniolli, Francesca Fiorentini, and James Gordley, A Case-Based Assessment of the Draft Common Frame of Reference, the American Journal of Comparative Law vol. 58 (2010), at 343 and Silvija Petrić, Nacrt Zajedničkog referentnog okvira za europsko privatno pravo, Zbornik Pravnog fakulteta Sveuč. Rijeka, vol. 30, br. 1, 473-513 (2009).

A devoted supporter-turned-to skeptic of secured transactions reforms, Roderick A. Macdonald put question marks next to Book IX of the DCFR - the books dealing with secured transactions law - whether it „might conveniently be adopted by diverse [European] states" in the pretext of some presumed calculus or economic dogma. See Roderick A. Macdonald, Transnational Secured Transactions Reform: Book IX of the Draft Common Frame of Reference in Perspective, Zeitschrift für Europäisches Privatrecht, vol. 17, No. 4 (2009), 745-746.

13 Subparagraph (d) of the second paragraph of section IX. - 1:103 pronounces that "the term retention of ownership device includes [... also] ownership of the supplier under a contract of consignment with the intention of the effect of fulfilling a security purpose."

14 Book IX section 3:303 reads as follows: „(1) For the purposes of the European registered for proprietary security no distinction is made between retention of owner- 
not clear how far that novelty aims to reach ${ }^{15}$ That can be easily seen if approaching this question from the perspective of UCC and in particular UCC Article 9, that law which has had the longest history and is therefore the most tested one as far as the subjection of consignments to the secured transactions regime is concerned.

Thirdly, to Continental European legal dogmatic (or systemic) thinking, consignment is a sub-type of agency not thought to have much connection (if any) with such credit-securing contracts as pledges or mortgages. The metamorphosis - destined to occur according to the DCFR - is comprehensible solely if one shifts from dogmatic (systemic) to functional thinking; something quite new on the Old Continent. Functional thinking, on the other hand, is the basic policy choice and feature of UCC Article 9 (i.e., the law of secured transactions), obviously used by the drafters of the DCFR as the source of inspiration. Unfortunately, neither the quite hectic US history of consignments, nor the complexity of the subject matter, makes the planned transplantation easy. These reasons further justify this paper and a tour to this otherwise quite neglected terrain of law.

Finally, in the era of overwhelming reform fatigue in CEE and the impotency of European harmonization efforts, it is quintessential to justify why it nevertheless makes sense to venture as far as to subject consignments to secured transactions law. Put simply: some branches of law can become a catalyst of economic growth. Secured transactions - or the law of credit securities - can achieve that by creating the necessary conditions and incentives for extension of trade and loan-credits. ${ }^{16}$ The ensuing discussion on the subjection of consignments to the secured transactions regime will hopefully properly show can that be possible; though consign-

ship devices and security rights. (2) Any reference in this Section to security rights includes retention of ownership devices."

15 This point seems to be stated by Reinhard Zimmermann as well, though not related (or not only related) to consignments; a contract and especially the rational of the subjection of which to secured transactions law is really unresearched in Europe. From Zimmermann's criticism perhaps the following claim seems to be most relevant to consignment law: „[...] the abundance of general provisions and open-ended concepts entailing a considerable expansion of uncontrolled judicial power [...]." Reinhard Zimmermann, The Present State of European Private Law, 57 American Journal of Comparative Law, vol. 57 (2009), at 492-93.

16 Trade-credit is the credit extended by manufacturers, wholesalers and suppliers by not requiring advance or immediate payment for the goods delivered. These credits are typically financed through forms of retained title (ownership). As opposed to that loan-credits are cash remitted to the debtor. UCC Article 9 departs from the presumption that these credit forms are equal, hence, it does not make a difference between the two contrary to some European systems. 
ments are only one type of secured transactions and examples of how can that be done. This should be the main guiding line when scared by the frightening complexity and detail of US laws on consignment as the leading financing-promoting model, though it is also a fact that law and economic growth has become a fashionable topic in the $21^{\text {st }}$ century ${ }^{17}$ and international lenders (e.g., World Bank) promote these ideas. CEE and other emerging markets should start pay more heed to these thoughts no matter how unorthodox they may turn out to be to lawyers trained according to European system thinking. It is to be noted also that the materialization of ideas like the one discussed herein are object also of regulatory competition and may be a factor attracting foreign capital.

\section{Preliminaries}

\subsection{WHAT IS A PARADIGM CONSIGNMENT TRANSACTION?}

Before we enter into details, we should try to delineate in simple terms what our central category denotes. This seems to be roughly the same in common and civil law systems: delivery of certain goods to a merchant for the purpose of sale subject to retained title (ownership). ${ }^{18}$ Here, the caveat to be added is that the definition of UCC is much more complex because it is functional aiming not only to determine what the distinguishing features of this particular transaction are but also to fix which of the various "consignment forms" should and should not be subject to the secured transactions system. Still, the description of conventional consignment by the doyens of US commercial law - White and Summers - may be a good starting point for our purposes:
"In a typical consignment an owner puts goods in the possession of a consignee with instructions to sell those goods to third parties. Normally, the consignor agrees to take the goods back if they are not sold. If the go- ods are sold, the consignee takes a percentage (say 20\%) of the sales price and remits the proceeds. Consignments are common in the marketing of certain goods, such as diamonds and books. A typical consignment has some of the economic characteristics of a loan against inventory for the consignor's capital enables the consignee to display inventory on its sales floor and to make sales the consignee could not otherwise make. Howe-

17 See, e.g., Kenneth W. Dam, the Law-Growth Nexus - the Rule of Law and Economic Development (Brookings Institution Press, Washington D.C., 2006).

18 While there are at common law significant differences between 'title' and 'ownership', for our purposes it suffices to state that the common law 'retained title' denotes roughly the same as civil law 'retained ownership'. Consequently the two will be used interchangeably in this paper. 
ver, consignment is not exactly the same as a secured loan, for it leaves

the risk of no sale on the consignor/seller not on the consignee/buyer."19

The main reasons on the side of the consignee for engaging in consignment are that they typically do not have enough money to purchase those goods, or they have no access to credit, or they do not want to assume more debt. The consignor, on the other hand, is led by the realization that "if a selection of these goods is displayed in the retailer's [i.e., consignee's] store ${ }^{\text {" } 20}$ it will be easier and cheaper to sell those items. Alternatively, the wholesaler or manufacturer may resort to consignment to introduce of a new line of merchandise to retailers, even with his representative present on the floor of the consignee for a few days to press the latter focus on the "marketing campaign“. 21 The transfer of the goods to the care of the consignee naturally presumes trust primarily on the side of the consignor, as he will run the risks of damage to goods, their loss and - of central interest to us - the possibility of losing the priority race with other creditors. Whether the consignee is to transfer the moneys received for the items sold only upon their sale or on a weekly basis, is a matter of contract, just as what will happen to the consigned goods is they will not be sold (though that is already a factor of importance to Article 9). Consignment - just like all the other commercial transactions - may have many variants (e.g., consignment 'on approval'), 22 though the conventional and especially consignment for the purposes of US secured transactions law presumes transfer of goods for sale. Still, some arrangements that are looked upon as consignments in one country might not necessarily be qualified as such in others, ${ }^{23}$ what inevitably makes our task of determin-

19 James J. White \& Robert S. Summers, Uniform Commercial Code (West, $6^{\text {th }}$ ed., 2010), at 1165 .

20 See Albert G. Sweetser, Financing Goods (Simons-Boardman Publishing Corp., 1963), at 65 . Even though this book is only of historic importance in the US today, for systems where consignment has been so far unknown, or exploited only in a very limited forms, and hence in which businessmen and financiers cannot jump straight away to the contemporary yet most complex business patterns, this book should be of relevance especially because of its concreteness and pragmatism. The normal caveats for using historic books and other sources of law though naturally do apply.

21 Id., at 63.

22 This sub-type of consignment is used in case of non-standardized goods when it is necessary to give the possibility of choice to the buyer like "precious gems, works of art, many types of musical instruments, oriental rugs, all kinds of collectors' items including postage stamps and coins, and certain types of furniture." See Sweetser, at 63.

23 Sweetser listed also the following as examples of consignment: distribution of newspapers and periodicals (,the wholesaler or publisher .... leaves more than enough to cover the retailer's possible sales [and] takes back the excess on his net delivery trip"), soft drinks (returnable similarly especially if for sale „at fairs, sporting contests, and 
ing which consignments should in Europe be caught by the secured transactions system harder.

In order to demonstrate how the subjection of consignments can create incentives for third party financiers willing to finance the consignee based on the inventory it has on its floor, mention must be made also of the so-called 'banker's consignment' - in the US known also as 'trust receipt' prior to the UCC. This transaction form, strictly speaking, is not a form of consignment but a separate security device that only grew out of consignments. ${ }^{24}$ Yet it is also one of those secured transactions the security interest created by which comes often into conflict with those of consignors. Put simply: its mention is needed to explain and exemplify why it makes sense to subject some forms of consignment to the secured transactions system.

Two preliminary terminology notes are a must here. The first relates to the use of the 'trust receipt' language, which has decreased in the US due to the unitary vocabulary introduced by the UCC. ${ }^{25}$ Irrespective that now the trust receipt holder is named normally simply as a 'secured creditor', it does make sense to refer to this particular type of secured transaction by its ancient name use it as it more clearly designates the particular financing model it was conceived for. Additionally, the DCFR seems to cover to this device under the designation of 'trust for security purposes, ${ }^{26}$ and as it is a security device that is known also in other parts of the world. ${ }^{27}$ The second

other public events"), or gift shops „especially handmade articles and antiques." See Sweetser, at 65 .

Note that some of these and the transactions listed in the previous note would not be 'consignments' for the purposes of UCC Article 9, like for example, consignment of consumer goods (Revised Version s. 9-102(a)(20)(C)).

24 See Albert G. Sweetser, Financing Goods (Simons-Boardman Publishing Corp., 1963), at 499 .

25 The new terminology introduced by the drafters of UCC Article 9 did not treat all pre-UCC transaction types equally. While chattel mortgage or trust receipt have been more fully substituted by the new terminology of 'secured transaction' (they are only listed as examples of pre-UCC transactions that have become subject to the system), 'consignment' remains named throughout the chapter as such. See, e.g., in the preRevised Version of Article 9 section 9-102 for the list of pre-UCC transactions and section 9-114 specifically devoted to 'consignment'. This in practical terms means that while a computer-based research of the text of UCC Article 9 with the research term of 'consignment' would lead to concrete results and sections containing exactly this term, that would not be the case if 'conditional sales' or 'trust receipt' would be used.'

26 DCFR Book IX section 1:101(2)(a).

27 For example, trust receipts are quite frequently used in the Far East irrespective that its legal status is far from being clear. A very illustrative case is the Malaysian United Malayan Banking Corporation Bhd v. Aluminex (M) SdnBhd [1993] 3 M.L.J. 587 as 
terminology note, to be borne in mind when reading this article, is that UCC Article 9 extends only to 'commercial' consignments because of why 'consumer' consignments - i.e., consignment of goods by consumers to a merchant for sale - now fall into the bailiwick of sales law exclusively. ${ }^{28}$

\subsection{THE LINKAGE OF CONSIGNMENTS TO SECURED TRANSACTIONS LAW}

\subsubsection{The Ostensible Ownership (False Wealth) Concern}

The hard to understand yet straightforward reason consignments have become covered by secured transactions law in the US in the first place is because they are in fact functionally very similar, if not equal, to other forms of non-possessory securities. If the legitimacy of such functional approach is subscribed to, then it is easy to see why consignment is the brethren of such secured transactions as chattel mortgage, conditional sales or [financial] ${ }^{29}$ leasing: it also creates divided ownership with the owner-consignor transferring the possession over the goods to be sold to the consignee subject to retained title. Through such a division of possession and title they may mislead other participants of the market by their ostensible ownership or 'false wealth.' As Warren and Walt put it „commercial consignments ... create an ostensible ownership problem for the consignee's creditors and purchasers. Potential lenders may assume that the merchant owns the inventory that it possesses. A consignee's senior inventory financer might rely on the consignee's unencumbered ownership of incoming consigned goods to extend subsequent credit to it. "30

These concerns UCC Article 9 now resolves through a complex matrix of priority and other rules. Yet even a cursory glance at the matrix in the Appendix will reveal that for UCC Article 9, indeed, this is one of the central concerns. The convoluted definition of 'consignment', or which types of consignments are covered by UCC Article 9 and which are not,

discussed by Hans Tjio in the article Personal Property Security Interests in Singapore and Malaysia in: Company Lawyer 1995, 16(1), 28-32.

28 See also section 2.2.2. below.

29 The brackets have been added because of the Eastern European reading audience to whom conditional sales as a distinct nominate and paradigm secured transactions is unknown. In Europe - with the exception of the common law jurisdictions - rather the conditional sales' derivatives 'financial' leasing or simply 'leasing' is what is known. Yet it has to be added that for the purposes of UCC Article 9 it is not the designation of the contract what matters. Hence, not only 'financial' leasing transactions are subject to it.

30 William D. Warren and Steven D. Walt, Secured Transactions in Personal Property (Foundation Press, 2007), at 349. 
serves primarily this end. As far as the non-covered ones are concerned, given that such consignments are 'obvious,' creditors cannot be misled, and therefore there is no false wealth problem either. As a result there is no need to subject those transactions to the requirements of UCC Article 9 to protect the consignor's interests from adverse claims. Therefore, UCC Article 9 extends only to those consignments in case of which it is not conspicuous that goods held by consignee are not his. As it was pronounced in a recent case, „the policy behind the UCC's treatment of consignments ... is to protect creditors of the consignee from claims of consignors that have undisclosed consignment agreements with the consignee that create secret and undisclosed competing interests in the inventory held by a consignee." 31

The position of purchasers from consignees is the first problem to be addressed. Their protection is achieved primarily through the rules that ensure that they acquire good title free of liens when buying from consignees. ${ }^{32}$ This principle could be presumed to be known to all modern systems as it is the basis of the trust and predictability so fundamental to all working markets (not necessarily to developed market economies alone). Irrespective of and above that, however, the consignment-related provisions of the pre-1999 Revised Version of UCC Article 9 - in addition to being located mainly not in Article 9 but in Article 2 on Sales - were subjected to the so-called 'sign-posting requirements' 33 or to filing according to Article 9. In other words, the system was keen to ensure that the clients and creditors of consignees were given notice of the divided ownership. ${ }^{34}$ The Revised Version of 1999 just further emphasized the

31 In Re Georgetown Steel Company 318 B.R. 352 (United States Bankruptcy Court, South Carolina, 2004).

32 Two sections of UCC Article 9 should be mentioned. Section 9-319 ensures that the consignee has equal rights as the consignor "for the purposes of determining the rights of ... purchasers for value of goods from, a consignee [...]. "Section 9-320 additionally declares that „a buyer in the ordinary course of business, other than a person buying farm products from a person engaged in farming operations, takes free of a security interest created by the buyer's seller, even if the security interest is perfected and the buyer knows of its existence."

33 White and Summers mentioned as an example the BFC Chemicals, Inc. v. SmithDouglass, Inc., 46 B.R. 1009, 40 UCC 1674 (E.D.N.C. 1985) case, in which the court required for compliance with UCC s. 2-326(3)(a) that the consigner has „show [ed] evidence of a sign in fact and that the sign was conspicuously placed at the consignee's place of business." James J. White \& Robert S. Summers, Uniform Commercial Code (West, $6^{\text {th }}$ ed., 2010), note 2, at 1165.

34 As White and Summers put it „[p]rior to the 1999 revision, most of the Code law on the rights of consignees and their creditors was found in section 2-326 of Article 2. In general, that section subordinated the consignor's interest to rights of the creditors of the consignee in any case in which the consignee did business under a different name than the consignor, unless the consignor could prove that the consignee was generally known 
same policy choice and made the whole system simpler by subjecting most commercial consignments to Article 9 and provision of public notice on the consignment by way of filing. It seems that European systems are much less vigorous in that respect and registration of consignments in a pubic register or sign laws are not routine matters; especially in the fledgling markets of CEE.

In jurisdictions where there is a high rule of law and in which bankruptcy proceedings are not exploited - successfully because of the deficiencies of the bankruptcy system - to defraud creditors (or where bankruptcy is still highly despised, carries with it a social stigma and hence are to be avoided at any price), this rule alone may be sufficient. Yet in countries, however, where "dealers" of motor vehicles or of other goods may easily "disappear" with the down payments or paid installments, using bankruptcy in fact as a legal shield to legitimize that, subjection of all such transactions - whether named or not as consignment - to a registration requirement might be not just a deterrent to a considerable number of dishonest "dealers" but also a tool to check on them even by consumer debtors. Put otherwise, a fresh look at the role sign posting or registration could play in Europe should also be of interest to consumer protection law. Admittedly, all that would be something quite new and time would be needed until a wider group could realize what values are hidden in a public registry containing information on a consignment, or a consignmentlookalikes; yet eventually it would have a beneficial effect on commerce.

In the common law world, the concerns caused by divided ownership - consignment being one of such transactions - are rooted in the famous $16^{\text {th }}$ century Twyne's Case, ${ }^{35}$ the consequence of which was that all forms of "[s]eparation of ownership and possession ha[ve] been viewed as a source of mischief toward third parties and, for that reason, as fraudulent." 36 Con-

to be dealing in goods of another, 'or the consignor complied with a relevant sign law showing its interest or filed a financing statement under Article 9." James J. White \& Robert S. Summers, Uniform Commercial Code (West, $6^{\text {th }}$ ed., 2010), at 1165.

3576 Eng. Rep. 809 (1601). In Gilmore's interpretation the facts of case were as follows. "[O]ne Pierce, who was in debt to Twyne as well as to another creditor who had instituted suit against Pierce, secretly deeded goods and sheep to Twyne in payment of his debt. Pierce, however, remained in possession and continued to deal with the property transferred to Twyne as if it was still his own. There was a good consideration for the transfer, since Pierce's debt to Twyne exceeded the value of the property transferred. Nevertheless the Pierce-Twyne transaction was held to be fraudulent, and therefore void against Pierce's other creditor, because of Pierce's continued possession. '[A] secret transfer is always a badge of fraud ... by reason of [Pierce's continued possession] be traded and trafficked with others and defrauded and deceived them." Grant Gilmore, Security Interests in Personal Property (Little, Brown \& Co., 1965), note \$2.1.at 24 .

36 Douglas G. Baird \& Thomas H. Jackson, Possession and Ownership: An Examination of the Scope of Article 9, Stanford Law Review, vol. 35, No. 2 (Jan. 1983), at 180. 
sequently, the entire history of US secured transactions law was a repeated circle starting by the invention of a new form of non-possessory security and its subsequent acceptance by the system at the price of abundant litigation and eventual subjection to the requirement of provision of public notice in some form. ${ }^{37}$ In case of consignments, this eventually led to the subjection of most types ${ }^{38}$ of commercial consignments to all or some of the requirements of the secured transactions system. This is visible also from the Appendix that clearly displays that 'obvious' consignments - in case of which it is unequivocally clear what the real status of the consignee is - are not caught by Article 9 as in their case there is no false wealth problem.

The ostensible ownership problem in the context of consignment arises because of two things: first, the consignee is in the possession of goods the title on which remains with the consignor, and secondly, the consignee is empowered to sell those goods in his own name. In other words, to the outside word he looks like the full owner of those goods having unrestricted rights to sell them. The retained title - if no public notice is given about its existence - remains a secret security known only by the parties to the transaction because of what the consignee may not just sell the consigned goods but may pledge them as well as collateral to obtain additional financing from third party creditors.

Under UCC Article 9, the requirement and method whereby public notice is given is named as 'perfection' of a security interest. To create an enforceable security interest, however, besides perfection, the so-called attachment requirement must also be fulfilled. ${ }^{39}$ While the latter is valid only inter partes, a security interest gets an erga omnes effect only upon perfec-

37 As Spanogle and Kirkpatrick put it „[...] the subsequent history of secured financing became of dynamic duet between creditors (and their attorneys) and the courts and legislatures to find mechanisms which would permit the separation of title and possession. Each attempt sought to manipulate the concept of title, and each was met with a legislative response. The validity of possessory security interests, such as the pledge, had never been in doubt, but such devices had little utility in financing business equipment, stock in trade and accounts [...]." Spanogle \& Kirkpatrick, Security Interests US Style: A Device for Financing Small Businessmen and Protecting Yourself in Liquidation, Bond Law Review, vol. 4, issue 2 (1992), at 116.

38 Note that not even all types of consignment are caught by UCC Article 9. What has been clarified by the Revised Version of 1999 is that no consignment is subject to sales law in UCC Article 9, what used to be the case prior to 1999. See the Appendix for the consignments and quasi-consignments not subject to Article 9.

39 See UCC s. 9-203(a) stating that a „security interest attaches to collateral when it becomes enforceable against the debtor with respect to the collateral, unless an agreement expressly postpones the time of attachment." Point 2 of the Official Comment to this section additionally states that "[s]ubsection (b) states three basic prerequisites to the existence of a security interest: value [has been given by the secured creditor][...]; [the 
tion. This is one of the conceptual differences between UCC and Continental European conceptions of creating a security interest: the American one is made of two differently nominated and conceptualized stages. The separation is most presumably rooted in the fact that in the past besides 'legal' - 'equitable' security interests were also known; the latter denoting a security interest in case of which some of the required elements was lacking for some justified reason. English law still distinguishes between 'legal' and 'equitable' charges but the drafters of UCC Article 9 have discarded the notion of 'equitable security interest' and consequently only one "type“ of security interest is recognized.

Today, besides taking possession (possessory pledge and its derivative forms), filing (simplified registration) is the most common method of giving public notice on the existence of the encumbrance. Though, in the world of investment property and some other types of collateral, acquiring of control ${ }^{40}$ and not filing is main perfection method - simply because that is how the affected industries are functioning. On the other hand, automatic perfection ${ }^{41}$ - i.e., cases in which no notice is provided - is a supplemental form of perfection justified by the fact that in certain situations it would be completely irrational to impose the burden of filing. Speaking of consignment, however, filing is the main perfection method.

\subsubsection{Incentives to Second Generation Financiers}

It is to be noted, however, that the reason for the transformation of consignments into 'security interests-creating secured transactions' is not only the protection of consignors and good faith purchasers of goods from consignees. The system was designed also to provide the second (or even third) financier of consignees not just with a notice on the consignor's interest but also with adequate assurances that their security interests and

debtor has] rights or power to transfer rights in collateral [...], ... plus satisfaction of an evidentiary requirement. [...]."

40 See Official Comment to UCC section 8-106, which states: „Obtaining 'control' means that the purchaser [of a security, like stock or bond] has taken whatever steps are necessary, given the manner in which the securities are held, to place itself in a position where it can have the securities sold, without further action by the owner." [Emphasis by the author.]

41 See UCC section 9-309 listing those security interests that are perfected „when they attach," i.e., without filing, taking possession or acquiring of control. E.g., purchasemoney security interests in consumer goods are one such category. This would be, for example, a TV set „purchased" by a consumer based on an installment credit contract yet with retained ownership. The reason for the exemption from filing requirements is that these goods depreciate quickly and it would be too burdensome and costly to both sides to the contract to impose filing for each such an item. 
the concomitant favorable priority positions will be well protected ${ }^{42}$ In other words, the system is based on the presumption that businesses normally live from credits extended by more financiers - what presumes that the system should allow the debtor to exploit the property it owns more times as collateral. Essentially this is the point because of why Europeans should seriously ponder whether it pays to recharacterize consignments and to embrace such a complex web of rules as exemplified by US law - besides the protection of consignors and consignee's clients. In times when governments in vain try to boost credits available to SMEs - that segment of the economy that provides the most jobs on both sides of the Atlantic - this is such a pragmatic consideration to which dogmatic (theoretical) ones should yield.

As it will be shown below, more variants of consignment or quasiconsignment transactions come within the purview of secured transactions law in the US. The main problem of the drafters of UCC Article 9 was, on one hand, how to delineate which of these transactions should be subjected to the secured transactions system. The other dilemma was what role should sales versus secured transactions law play in the life of consignments? The Solomonic solution of the 1999 UCC revision - after decades of tug of war - removed consignments entirely from Article 2 on sales.

Put simply, the commerce and financing-friendly realization is that protection of the financiers (creditors) of the consignee (in addition to the protection afforded to the consignor who is also a 'secured creditor' in the eyes of the system), who - if certain that their "interest is in fact superior to that of other creditors with respect to particular collateral, [and] the more sharply defined are the advantages of being a secured creditor" 43 - would be more willing to extend credits to consignees in addition and above the consignment. In fact, the US system- and hopefully also the DCFR - primarily aims indeed to allow the secured party „to ascertain with precision the status of existing creditors and the amount of their claims, as well as the risks posed by subsequent parties. " 44

42 As a UC bankruptcy court put it in the famous In Re Georgetown Steel Company, LLC v. Progress Rail Services Corp. 318 B.R. 351 (2004) stated: „[The] purpose of 'consignment' provisions of Article 9 of the Alabama Uniform Commercial Code (UCC) is to protect creditors of consignee from claims of consignors that have undisclosed consignment agreements with consignee that create secret and undisclosed competing interests in inventory held by a consignee."

43 Douglas G. Baird \& Thomas H Jackson, Possession and Ownership: An Examination of the Scope of Article 9, Stanford Law Review, vol. 35, No. 2 (January 1983), at 179.

Id. 
This could be proven even indirectly by the fact that UCC Article 9 extends only to 'commercial' and not to 'consumer' consignments. ${ }^{45}$ This policy, however, was introduced not just because it was deemed to be „unreasonable to require 'most natural persons' who deliver their work [or used goods] to a consignee to precisely follow UCC filing requirements" 46 but also because it was unrealistic to expect that consumer consignors „were in fact crafting 'a subterfuge for inventory financing. "[Emphasis added.] ${ }^{247}$ In other words, in consumer consignment cases it is not the normal course of dealings by the consignee to get financing on the strength of the consigned goods. Part of the story is that the exclusion was aimed also at protecting consumer consignors more than their merchant brethren and hence now due to the exclusion of consumer consignments from under UCC Article 9 "those goods are not subject to the attachment of creditors in a bankruptcy [of consignee]. " 48

\subsubsection{Trust Receipts and Consignments}

To illustrate what has been said in the previous sub-section, a few words ought to be devoted to trust receipts for this distinct type of independent security devices grew out, indeed, from consignments. In the US, these transactions were first used exclusively by large city banks to finance imports somewhere around the end of the $19^{\text {th }}$ century. Later they were adapted to a completely different field: automobile financing. The transformation occurred because of automobile manufacturers led by Henry Ford, „a crotchety individualist, [...] sought to free themselves from the clutches of the banks by insisting that all cars be paid for in full and in cash before they left the factory. "

45 In a recent consumer consignment case, a consumer (i.e., not a business) consigned a recreational vehicle (RV) to a Tennessee RV dealer (i.e., merchant) for sale to a third person. The court concluded that „Article 9 was not applicable because Article 9 only applied to consignments of goods that were not consu8mer goods". In RE Music City RV, LLC 304 S.W. $3 \mathrm{dc} 806$ (Supreme Court of Tennessee, 2010).

46 Experts argued that the filing requirement should be eliminated as that would be inappropriate „e.g., [in case of ] the delivery for sale of consumer goods by a natural person or art by artists." Permanent Editorial Board for the UCC, Report of the Article 9 Study Committee [87(1992)] cited in Hilary Jay, A Picture Imperfect: the Rights of Art Consignor-Collectors when their art Dealer Files for Bankruptcy 58 Duke L.J. 1859 (2009), fn. 187.

$47 \quad$ Id.

48 Cashauna C. Lattimore, In Tennessee, Where Goods are Consigned to a Merchant and the Merchant Declares or is Forced into Bankruptcy, such Goods are not Subject to Attachment by the Merchant's Creditors - In RE Music City RV, LLC 304 S.W. 3 dc 806 (Supreme Court of Tennessee, 2010), 12 Transactions: Tenn. J. Bus. L. 225 (Fall, 2010).

49 Grant Gilmore, Security Interests in Personal Property (Little, Brown Co, 1965), at 95. Black's Law Dictionary defines 'floorplan financing' as „[a] loan that is secured by 
the cars. Hence, the dealers were forced to borrow money somewhere. As commercial banks refused to extend financing directly to automobile dealers, the so-called sales finance companies stepped in yet to whom banks were willing to lend money; thereby the trust receipt, a tripartite financing pattern was invented. As in both cases the asset type used as collateral was the inventory on the floor of the dealer-consignee-debtor, these financing methods came to be known also as forms of 'floorplan financing'. ${ }^{50}$

The common law trust receipt theory and in the exports already proven business pattern was then employed to solve three problems. First, a simplified filing method was introduced not requiring filing on a carby-car basis. Through the provision of public notice, finance companies were protected also from fraud by debtors. The other important novelty was that trough the trust receipt the title moved from "manufacturer to finance company to ultimate purchaser, without ever being for an instant in dealer. " 51 This was a proper solution for the security concerns of the financier. Last but not least, trust receipts allowed the financier to avoid stepping into the shoes of the seller and thereby to become liable for quality, quantity and fitness for a particular purpose. ${ }^{52}$

The automobile trust receipt had after World War I a curious history because the first response of many states was that the trust receipt is nothing else but a disguised chattel mortgage or a conditional sale. However, as by 1935 it became a statutory device based on the Uniform Trust Receipt Act in the commercially important states, trust receipts turned into ac-

merchandize and paid off as the goods are sold. Usually such a loan is given by a manufacturer to a retailer or other dealer (as a car dealer). „Similar definition was given by the court in Excel Bank v. Nat'l Bank of Kansas City, 290 S.W. $3 d 801$ (2009): „Floor plan financing is a method of financing where a lender provides money for the purpose of allowing a dealer of goods to buy inventory that is later resold to the consumer."

50 Admittedly, to lawyers and businessmen from CEE, this tandem might be similar to the operational versus financial leasing - likewise typically defined along the lines of two- versus a tripartite transaction. The facial resemblance is, however, much more than that given that each of these transactions are based on the exploitation of title (retained title) as the main security device and hence they are to certain extent functional equivalents.

51 Id., at 97.

52 Albert G. Sweetser, Financing Goods (Simmons-Boardman Publishing Corp., New York, 1963), at 499. As he put it „[w] hile the banker normally is not, and almost never would want to be, in the position of a seller of goods, it is possible for him to obtain some of the security of the consignor's position as owner of the goods by paying the supplier for the goods for the account of the borrower. In this way the banker obtains an interest in the goods prior to the acquisition of any interest in them by the borrower. The banker is than in the position to release the goods into the possession of the borrower but to retain title in his own name. This is accomplished by releasing them under a trust agreement in which the bank is named as entruster and the borrower as trustee of the goods for the benefit of the entruster." Id. 
cepted yet "highly specialized devices which were not to be generally available as a substitute of either the chattel mortgage or the conditional sale." 53 By 1963 the Uniform Act had been adopted by thirty nine states and two territories, though in most of them it was replaced by the adoption of the UCC. 54

From a perspective of emerging markets, the logical question that ought to be raised at this point is how was that possible? Obviously, without special rules - involving filing and notices - none of that could have become a routine practice as the consignor's retained title would have enjoyed priority over the claims of the trust receipt (or other) creditor(s). Put simply, UCC through 'legislative fiat' created rules that made the trust receipt creditor - the second generation financier-secured creditor interested to extend credit to consignee on the strength of the trust receipt device utilizing the inventory on the floor of the debtor as collateral. 'Legislative fiat ${ }^{55}$ simply meant artificial recharacterization and "degradation" of the consignor's retained title (ownership) to "mere" security interest. ${ }^{56}$ The result of this transformation in effect is that the "creditors of, and purchasers from the consignee can take judicial ${ }^{57}$ liens and security interests in the consigned goods even though they belong to the consignor. "58 In order

$53 I d$., at 99.

54 Id., at $500-01$.

55 William D. Warren and Steven D. Walt, Secured Transactions in Personal Property (Foundation Press, 2007), at 350-51.

56 This process is not uniquely applied only to consignments: the same formula catches also the retained titles in conditional sales and leasing transactions, which - contrary to European conceptions (this time including also English law) - are also subject to the secured transactions system in the US. This cannot but lead to the conclusion that the transformation of consignment cannot occur in isolation from the parallel identical treatment of other title financing transactions - what in CEE typically is limited to the versions of the newcomer contract known even by local languages as 'leasing.'

57 Not clear here why only 'judicial' liens. Security interests are 'consensual' liens, which can be enforced without resort to courts - i.e., can be enforced even without creating a 'judicial' lien. Besides, the main goal of the recharacterization is to allow financing on the strength of consigned goods by financiers different from consignors.

58 This follows from point 2 of the Official Comment to section 9-319 which reads: "for purposes of determining the rights of creditors of, and purchasers for value of goods from, a consignee, while the goods are in the possession of the consignee, the consignee is deemed to have the rights and title to the goods identical to those the consignor had or had the power to transfer." See also William D. Warren and Steven D. Walt, Secured Transactions in Personal Property (Foundation Press, 2007), at 351.

The consignor can obtain priority of the floor planner's security interest if he a/ files a financing statement (i.e., holding the certificates of title is insufficient) and b/ gives a written notice to the floor planner before the filing „stating that it expects to deliver certain vehicles on consignment to the dealer." See Roger D. Billings, Jr., Floor Plan- 
to acquire such a superior priority, complex filing-cum-notification steps must be taken to achieve the status of purchase money security interest. ${ }^{59}$ The system is justly being criticized as convoluted because of why in practice the holders of conflicting security interests over the same inventory resort to inter-creditor agreements.

This recharacterization is one of the most problematic aspects of the US system for Europeans to accept. ${ }^{60}$ Still this is the price the system has to pay in order to allow for the appearance of more financiers on the scene besides the consignor, who - having often a monopolistic position - might not be interested even in allowing another consignor's goods to be marketed and hopefully sold from the floor of the consignee, let alone the appearance of other financiers. In other words, besides a better protection of consignors and good faith purchasers from consignee, the more important stake inherent to recharacterization of consignments lies exactly in this. Yet if more financing options are the ultimate goal of changes, then hardly could Europe do less than what the drafters of UCC Article 9 had done. This would not, however, be possible without a radical mind shift. ${ }^{61}$

\subsubsection{Prevention of Bypassing the System}

The US history of secured transactions is the proof that businessmen faced with the regulatory burden of the sort known to UCC Article 9 (i.e., registration, complex priority rules, restrictions on enforcement as well as licensing and capitalization requirements) will be tempted to bypass them

ning, Retail Financing ...(Oct. 2010), Floor Plan. Auto. Industry \$1:51.See also UCC section 9-324 'Priority of Purchase Money Security Interests'.

59 Lessne, Inventory Financing - Practicing Law Institute, PLI Order No. 18595, 914 PLI/Comm 61 (2009).

60 As aptly stated by Ron Cuming: „There are two features of the U.C.C. Article 9 approach that appear to be troublesome even to those who are attracted to it. The first is the total reconceptualization that it requires in the context of types of transactions that traditionally are not viewed as secured financing devices [...]. The second feature ... is the extent to which it requires a bifurcated approach to the characterization of certain types of transactions. Since a title retention sales contract or a lease falls within a secured financing regime $s$ not the owner of the goods sold or leased... What is troublesome is that outside this regime, the recharacterization might not be acceptable with the result that the same transaction is viewed differently depending on the legal issues being addressed." Internationalization of Secured Financing Law, in: Ross Cranston (ed.), Making Commercial Law: Essays in Honor of Roy Goode (Oxford Univ. Press, 1999), at 522.23. [Emphases by the author.]

$61 \ldots[. .$.$] In the new framework, finance and other professionals are obliged to change$ their conceptual thinking. A mind shift is needed [...]." Gerard McCormack, Reforming the Law of Security Interests: National and International Perspectives, Singapore Journal of Legal Studies 1, 12 (2003). 
by misnaming their transactions, or otherwise, if not prevented by the system. This is a concern that is normally not written much about by US scholars because due to UCC Article 9's comprehensive system this is not a major problem anymore: one of the main goals of bringing all transactions that perform a security function by utilizing personal property as collateral was, indeed, to prevent exactly that.

In fact, besides true-yet-non-obvious ${ }^{62}$ consignments, the other consignment type subject to UCC Article 9 is a 'consignment that secures an obligation' - what in effect is nothing else but a disguised secured transaction. As such it is now under the Revised Version treated completely as security interest-creating transaction and all provisions of Article 9 fully apply to it. ${ }^{63}$ These are the living proofs that, at least in the US, consignments can be used (and misused) to obtain financing on the strength of the consigned goods from a financier different from the consignor.

Logic would dictate that in the European compartmentalized systems, especially without appropriate regulation, such maneuvers should be easier. Likewise, there is no legitimate reason to believe that European businessmen would be less inclined to bypass a burdensome system if less onerous functional equivalents are handy. In the lack of empirical data directly on consignments, let us mention Poland's problems with the coexistent exploitation of two irreconcilable credit-security systems: the German registration-hostile fiduciary securities („kautelarische Sicherheiten“) and the common law-inspired yet registration-based system enshrined into the modernized pre-WW II registered pledge law. ${ }^{64}$ One of the rea-

62 B1 type consignments in the Appendix below. In the case In Re Georgetown Steel Company v. Progress Rail Services Corp., LLC 318 B.R. 352 (US Bankruptcy Court, D. South Carolina, 2004) this type of consignment was named „conventional“.

63 As White and Summers put it: „One way to think of [conventional versus these disguised consignments] is to say that a classic consignment creates an interest that behaves like a security interest for the first five parts of Article 9 but not for the sixth, whereas a consignment 'that secures an obligation' is a security interest for all parts of Article 9. "James J. White \& Robert S. Summers, Uniform Commercial Code (West, $6^{\text {th }}$ ed., 2010), at1167.

64 For the general history of Polish secured transactions law see John A. Spanogle, Secured Transactions Law in Eastern Europe: the Polish Experience as an Example 31 Thomas Jefferson Law Review 279, 291 (2010) and Krzysztof Kaźmierczyk \& Filip Kijowski, Enforcement of Contracts in Poland, in: Stefan Messmann \& Tibor Tajti (eds.), CEE Case Law - Enforcement, volume II, at 521, 607.

As described by the authors of the latter, the less onerous and cheaper alternative will always be favored by businessmen. In case of Polish security devices this concretely meant the favoring of the German transplants - the security assignments over the registered pledge because they are created by mere agreement as opposed to the registered pledge that required also court registration. Namely, "[i]n contrast to the 
sons for the popularity of the German devices was clearly the highly inflexible entry requirements imposed on 'registered pledges.' ${ }^{65}$ This is an important momentum given that retained title - simple, expanded and extended ${ }^{66}$ - are suppliers' most favored security devices in much of Continental Europe. As their creation and the related law is clearly simpler and cheaper, though especially in the context of bankruptcy less predictable, they represent non-negligible functional alternatives of the complex rules offered by the US System. ${ }^{67}$

Few lines from In Re Georgetown would corroborate the argument: "To recognize the Agreement [named by parties as 'Consignment Agreement'] as some type of consignment beyond the application of Article 9 of the UCC, as adopted under Article 9A of the Alabama Commercial Code, would allow [the Defendant] to circumvent [emphasis added] the secured transaction provisions adopted by so many states. "68

simple notice-filing system known in the US, according to which the registrar does not verify the content of security agreement ... there is far-reaching court scrutiny of applications in Poland [what] considerably prolongs the time necessary to perfect the security (even up to several weeks). "Id., note 168, on page 609-10.

65 See, e.g., John A. Spanogle, Secured Transactions Law in Eastern Europe: the Polish Experience as an Example 31 Thomas Jefferson Law Review 279, 291 (2010).

66 According to German law (and those CEE laws that have transplanted these concepts like Austria or the Czech Republic), simple retained ownership is a contractual clause covering only a specific identified movable. If the ROT extends also onto the products and proceeds of the movable (i.e., after-acquired property) that is 'extended ROT. If the same ROT secures not just the initial debt but also future advances, the ROT is known as 'expanded'. While it is questionable whether the 'extended' and 'expanded' language better expresses the essence than 'after-acquired property' and 'future advances' - obviously the same business needs brought about such changes both in Germany and the US. See, e.g., Rolf Serick, Securities in Movables in German Law: An Outline (Kluwer, 1990); Tibor Tajti, Comparative Secured Transactions Law(Akadémiai könyvkiadó, Budapest, 2002), Chapter on German law as well as Tibor Tajti, Viehweg's Topics, Article 9 UCC, the „kautelarische Sicherheiten“ and the Hungarian Secured Transactions Law Reform, 6 Vindobona J. 93(1) (2002) (downloadable at <http://www.SSRN.com>).

67 This system is simpler yet not without its vices. Here it is justified to cite only a few sentences from the doyen of German law, Ulrich Drobnig: „[In Germany], publicity by registration is replaced by a presumption of constructive knowledge of the security right [meaning that] [m]erchants are expected to know that nowadays most items of major equipment are bought on credit and that the purchase items serve as security." Yet as he admitted "the rate of litigation in cases of the buyers' bankruptcies is very high and as a result at least some of the initial saving of cost and time due to non-registration is later lost in litigating with the insolvency administrator." See Ulrich Drobnig, Basic Issues of European Rules on Security in Movables, in: John de Lacy, the Reform of UK Personal Property Security Law (Routledge - Cavendish, 2010), at 448.

68 In Re Georgetown Steel Company, LLC v. Progress Rail Services Corporation, 318 B.R. 352 (United States Bankruptcy Court, D. South Carolina, 2004). 


\section{On the Nature of Consignment Contracts}

\subsection{THE CONTINENTAL EUROPEAN PERSPECTIVE: SYSTEM THINKING VERSUS THE DCFR'S INTENDED RECHARACTERIZATION OF CONSIGNMENTS}

As this article is not concerned with the dogmatic classification of consignment contracts, nothing more than a brief digression should suffice. The beauty of the question what the legal nature of consignments is that businessmen and practicing lawyers alike invariably know what this specific contract is about. ${ }^{69}$ Moreover, on both sides of the Atlantic consignment is linked primarily to agency contracts and their derivative forms. A renowned German author simply referred to it as a sui generis contract $^{70}$ containing elements (or being used in combination with)other nominated contracts; primarily some forms of trade representation (i.e., agency or in German „Vertragshändlervertrag"), deposit(in German: „Verwahrungsvertrag") and sales. This formula made of these three elements - i.e., entrusting or depositing of goods with an agent (consignee) for the sake of selling the goods for the account of the entrusting consignor yet without transferring title (ownership) - is what consignment is about.

Due to the significant differences as far as the meaning, forms, reach and regulatory approaches to agency ${ }^{71}$ are concerned on the two continents, not only the differing concepts but terminology as well may easily hinder comprehension. ${ }^{72}$ The different criteria for classification of agency

69 Hence, the meaning attributed to the verb 'consign' by the US Black's Law Dictionary might be taken to be the minimum common denominator, which reads: consign means "[t]o give (merchandize or the like) to another to sell, usu. with the understanding that the seller will pay the owner for the goods from the proceeds." Bryan A. Garmer (editor in chief), Black's Law Dictionary - Deluxe Ninth Edition, 2009).

70 Roderich Thümmel, in: Rolf A. Schütze \&Lutz Weipert (eds.), Münchener Vertragshandbuch, Band 4, Wirtschaftsrecht III (C. H. Beck, München, 6th ed. 2007(, (pp. 113 - 146), at 135.

71 For example, according to de Cruz the so-called „Kommissionar" contract (typically translated as 'commission agent') does not qualify as 'agency' because the Kommissionar acts in his own name and the existence of agency and the principal is undisclosed. See Peter de Cruz, Comparative Law in a Changing World (Cavendish, $2^{\text {nd }}$ ed., 1999), at 375.

72 As Folsom and Gordon put it „Agency law may differ substantially in a foreign nation, especially nations with civil law tradition systems [...]. [Additionally, the laws of some nations seem to blur the distinction between [distribution through independent foreign agents and independent foreign distributors, and thus use of an independent foreign distributor may not always achieve the protection sought. [...]. [T] he law of the foreign nation may regulate the nature of the agency relationship substantially more than is the case in the US. Civil law commercial codes may provide extensive detail regarding the 
contracts leading typically to a three-partite Continental European ${ }^{73}$ versus the US dualistic categorization is what a priori causes unease. Yet for our purposes it is not the type of the agency contract that matters but whether there is consignment of goods for sale; irrespective whether the transaction at stake is designated by one of the known contract forms of trade representation yet with consignment of goods or is merely a transaction named as 'consignment.'

Similarly, if we depart from the delineation of what paradigm (conventional) consignment means, only those transaction forms are of interest to secured transactions law where the title (ownership) on goods are not transferred onto the agent definitively and the agent/consignee acts in his own name and is "generally not known to be substantially in the business of selling the goods of others" ${ }^{74}$ This is so as only in such situations ostensible ownership, or false wealth concerns arise. In case of what is designated as 'obvious' consignment in the Appendix below, none of these preconditions is existent. Talking of US law, consignment-type false wealth concerns can arise per definition in case of distribution through 'independent foreign agents, who may be called a sales representative or commission agent;' but not in case of 'independent foreign distributors. ${ }^{75}$

agency relationship. Additionally, these rules may be mandatory and not be subject to alteration by contract. Foreign law may outline different forms of agents whose powers are quite carefully delineated. The powers may or may not be in conflict with what the US party might wish to arrange by contract. [...]." See Ralph H. Folsom, Michael Wallace Gordon, John A. Spanogle, Jr., and Peter L Fitzgerald, International Business Transactions - A Problem Oriented Coursebook (Thomson-West, $9^{\text {th }}$ ed., 2006), at 238-39.

73 French and German laws share the features that they have no general treatment of agency but rather know for three types of representation forms: 1/ commercial agents; $2 /$ independent agents and 3/ commission agents. See Peter de Cruz, Comparative Law in a Changing World (Cavendish, $2^{\text {nd }}$ ed., 1999), at 375. CEE countries seem to have a similar tripartite system. For example, the Act on Obligations (often translated as a 'Code of Obligations) of all the ex-Yugoslav successor states also lists three such contracts: 1/ „komision“ (commission agent); 2 / „trgovinsko zastupanje“ (commercial agent) and 3/ „posredovanje“ (middleman).

74 Goods given to a carrier for delivery to a designated client is also termed 'consignment.' The DCFR also uses the term 'consignment' in Book IV.A. section 2:204 devoted to carriage of goods. Given the important transformations consignment is foreseen to undergo under the DCFR and as one of the central issues is exactly what transactions - named as 'consignment' or without such designation - should be caught by the new system, the use of this term related to carriage of goods might not be the best solution.

75 See Ralph H. Folsom, Michael Wallace Gordon, John A. Spanogle, Jr., and Peter L Fitzgerald, International Business Transactions - A Problem Oriented Coursebook (Thomson-West, $9^{\text {th }}$ ed., 2006), at 238. 
These questions deserve merit because due to European system thinking and the novelty of the idea of reconceptualization of consignments answering of what kinds of [agency] contracts should be caught by the new regime is one of the first questions to be answered. In other words, proper answer should be given on the relationship of agency, consignment and secured transactions laws based on European conceptions and realities.

In the post-socialist countries consignment has an additional trait. In the former Yugoslavia, for example, consignment was a contract limited to cross-border trade and typically the Yugoslav agents of foreign manufacturers kept goods on consignation. ${ }^{76}$ This was so as foreign direct investment and direct conduct of business by westerners in these countries was simply prohibited. Western manufacturers and wholesalers were forced by socialist laws to find a local partner to enter these markets. The second obvious reason for consignments' use exclusively in trade with capitalist states was the shortage of foreign currencies in these countries and the restrictions on the possession of foreign currencies by businesses and the citizenry. As a result western companies wanting to market their goods on these countries could not require normally the upfront payment of goods to be shipped but had to establish consignment warehouses with local

76 The Common Position of the $20^{\text {th }}$ Session of the former Yugoslav Republics' Supreme Courts („22, Zajednička sednica vrhovnih sudova“) No. 82/12-02 from 1982 is illustrative both $1 /$ of the statutory limitation of consignments to agents and distributors of foreign companies in Yugoslavia, and 2/ the dubiousness on the legal nature of consignment. Ad the first, the 1977 Act on Exchange of Goods and Services with Foreign Countries („Zakon o prometu robe i usluga sa inostranstvom;“ Official Gazette of the federal state No. 15/77) keeping of consignment warehouses for warehousing of foreign goods was defined to be a form of representing foreign companies („poslovi zastupanja stranog preduzeća") - or a form of agency. A separate regulation, Regulation on the Representation of Foreign Companies in the Field of Sale of Goods in Yugoslavia („Uredba o poslovima zastupanja stranih tvrtki u Jugoslaviji u području prometa robe;“ Official Gazette No. 20/78) even foresaw what elements such a consignment should have - though without giving definite answer on the legal nature of the transaction.

As far as the legal nature of consignment was concerned, the Position quite hesitantly found elements of three contracts in consignments: sales, agency and the so-called mandate contract („ugovor o nalogu"). Though, the Position itself placed the distinguishing feature on whether the consignee sold the good to the third party buyer in his own name but for the account of the foreign consignor. However, as even these specific laws allowed the parties to foresee otherwise, the definition and the legal nature of consignment remained open ended; virtually up until today and it seems in most of the successor countries of the former Yugoslavia. The crucial point to be realized is, however, that no firm conception has emerged on that issue in the West Balkans and hence the DCFR's intention to bring consignments under IX Book on secured transactions has insurmountable hindrances neither in theory nor in business practice. 
agents. ${ }^{77}$ It is valid to presume that this perception of consignment has remained the prevailing up to date; at any event the author of this paper is not aware of any quantitative data on the size of purely domestic consignment businesses in CEE.

The court decisions dealing with consignment from CEE are scarce, what already should be telling on the frequency of the use of it. To take the example of ex-Yugoslav jurisdictions, as consignment had not become a nominated contract in the Act on Obligations - initially passed in 1977 and then inherited (and amended more times) by all successor states of the former Yugoslavia - it if fair to presume that the legal nature of consignments has remained an open issue. For example, Serbian courts have also tried to grapple with the seemingly simple legal nature of consignment. ${ }^{78}$ Yet it is fair to presume that consignment is not perceived in these countries, just as in much of CEE, as a form of secured transactions. It is a more interesting question what the economic effects of a more widespread use of consignments perceived as financing methods by purely local businesses would be. Or, whether the DCFR's proposed subjection of consignment to registration (or filing) and other rules of secured transactions law could ease, for example, the financing of SMEs?

It is likewise unclear to what extent has floorplan financing become domesticated in these countries - including using of goods "on the floor" of the consignee that are displayed next to consigned goods.

77 For example, while the German car producer Volkswagen required its dealers from the West to purchase the cars to be shipped to them, it entered the socialist markets via consignment warehouses run by local agents. Interview with Prof. Stefan Messmann, the former legal counselor of VW (28 October 2011).

78 In the case Pž 3552/04 this definition was given by the court: „Consignment is not a form of sales contracts but a type of sales consignment combined with warehousing of the goods in which the consignor obliges itself to deliver to the consignee specific goods, who shall safeguards and keep the goods in his warehouse (i.e., consignment warehouse) and sell those goods when possible to third parties in his own name but for the account of the consignor. The consignor has the right to request the return of his goods from the consignee, who is obligated to do that if he fails to sell goods. The consignment relationship may be a type of agency relationship if the consignee promised to sell the goods from the consignment warehouse not just for the account but also in the name of the consignor. [...].“

The text reads in Serbian as follows: „Konsignacija nije vrsta kupoprodajnog odnosa već vrsta prodajnog komisiona kombinovanog sa uskladištenjem robe u kojem komitent - konsignat preuzima obavezu da pošalje komisionaru - konsignataru određenu robu, $s$ tim da konsignatar robu čuva na svom skladištu (tzv. Konsignaciono skladište) $i$ da prema ukazanoj prilici prodaje robu trećim licima u svoje ime, a za račun konsignanta. Konsignant ima pravo da zahteva da mu se roba vrati, a konsignatar je dužan da vrati robu konsignantu ako ne uspe da je proda. Konsignacioni odnos može biti jedna vrsta zastupničkog odnosa ako je konsignatar preuzeo obavezu da robu sa konsignacionog skladišt aprodaje ne samo za račun, nego i u ime konsignanta. [...]." 


\subsection{THE US PERSPECTIVE: WHY ARE CONSIGNMENTS MORE INTERESTING TO SECURED TRANSACTIONS THAN TO AGENCY LAW?}

It is commonly known that UCC, which - contrary to European 'gapless' codes - is not covering the entirety of commercial law. Agency law is the best example of what important fields of law have been left out by Karl Llewellyn and his team. Had agency law become part of UCC, it is more than certain that agency law would have become not just more harmonized but it would have turned also into a much more certain area of law - eventually affecting also consignment and secured transactions law. For our purposes, however, it is of importance that agency law is linked to consignment law as it „creates an agency relationship between the consignor and the consignee ${ }^{\text {“79 }}$ - as opposed to 'consignments intended as security' that are "really conditional sale[s] rather than an agency. "80 Court precedents and the Restatement (Second) of Agency contain factors how to distinguish the two; though no simple formula to achieve that has been formulated yet. ${ }^{81}$ It is to be added that in US agency is perceived to be a kind of omnipresent 'doctrine' affecting somehow the life of most branches of law - what seem not to be the case in European civilian systems where agency is primarily looked upon as a form of contract, part of the law of obligations. ${ }^{82}$

However, in the US it was not agency law that dealt with the most with consignments but the UCC tandem of sales (Article 2) and secured transactions law (Article 9). This is one of the crucial differences between approaches to consignment on the two sides of the Atlantic. To US law, in

79 Richard F. Duncan, William H. Lyons and Catherine Lee Wilson, the Law and Practice of Secured Transactions: Working with Article 9 (Law Journal Press, New York, date of original publication: 1987, update of 2011), at $\$ 1,04$ (3)(a).

80 Id.

81 According to the Restatement, a transaction is a conditional sale rather than an agency (true consignment) if „1/ the consignee gets legal title to and possession of the material; 2/ the consignee becomes responsible for an agreed price; $3 /$ the consignee can fix the price at which he resells without accounting to the consignor; 4/ the goods are delivered to the consignee incomplete or unfinished, with the understanding that the consignee is to complete the process; 5/ the risk of loss by accident is on the consignee; 6/ the consignee deals with the goods of persons other than the consignor; and 7/ the consignee deals in his own name without disclosing that the goods are those of another." Id, footnote No. 55 .

82 As DeMott put it ,agency relationships are numerous and varied and include employment, lawyer-client relationships, and the agency created by partnership." See Deborah A. DeMott, A Revised Prospectus for a Third Restatement of Agency, University of California, Davis, vol. 31 (1998), at 1037. 
other words, of primary interest was not where to place the consignment contract in the abstract hierarchy and classification of commercial transactions but to protect the outside world from the ostensible ownership inherent to it. In order to entertain this goal, two essential policy choices had to be made. While the first was whether to make use of the paraphernalia of sales or secured transactions law for that purposes, the other was which 'consignment' forms (named or thought to be 'consignments') should be left out from such a targeted regulation? It is fair to presume that these are the basic questions that should be tackled by Europeans as well - the pivotal question is whether the DCFR has paid due considerations to them.

In the light of the above and to determine which consignment forms are of interest to secured transactions law in the US, now it is legitimate to take a look at the full definition of the 1999 UCC Article 9 Revised Version's definition of 'consignment'. Under it, consignment is a transaction "regardless of its form, in which a person [e.g., manufacturer or wholesaler] delivers goods to a merchant for the purpose of sale. " ${ }^{\text {"I3 }}$ In other words, the crucial elements are that: $1 /$ the goods must be consigned to a 'merchant,' $2 /$ directly or ultimately ${ }^{84}$ for the purpose of sale of those goods; $3 /$ the merchant must be authorized to "sell the goods on behalf of the consignor, " 854 / the consignee has the obligation to return the goods if unsold and not merely an option to return them, and $5 /$ the given transaction is not specifically excluded because of some particular policy reason. ${ }^{86} \mathrm{To}$ recapitulate, in addition to conventional elements of consignment, Article 9's definition contains also exclusions that can be explained solely by the particular policy choices inherent to secured transactions law.

83 UCC section 9-102(a)(20). (1999 Revised Version).

84 The 'ultimately' here is meant to denote that even such transactions would qualify as consignment in case of which the goods are delivered first for some form of processing and sale only after that stage. See Official Comment 14 to UCC section 9-102 which says "If the goods are delivered for another purpose as well, such as milling or processing, the transaction is a consignment nonetheless because a purpose of the delivery is 'sale'. On the other hand, if a merchant-processor-bailee will not be selling the goods itself but will be delivering to buyers to which the owner-bailor agreed to sell the goods, the transaction would not be a consignment. See also the case In Re Georgetown Steel Co., LLC, 318 B.R. 352, 358 (Bankr. D.S.C. 2004).

85 See John Francis Hilson, Asset-Based Lending - A Practical Guide to Secured Financing (Practising Law Institute [PLI\}, $6^{\text {th }}$ ed., July 2010), at $\$ 15: 2.11(\mathrm{~A})(1)$ page 15.13.

86 UCC s. 9-102(2) excludes three categories of transactions from the definition of 'consignment': 1 / transactions where "the aggregate value of the goods is less than $\$ 1,000$ at the time of delivery [and] with respect to each delivery;" $2 /$ "transactions that were consumer goods immediately prior to delivery to the merchant" and 3/ "transactions that create a security interest that secured an obligation. 
Another difference to Europe, though of lesser importance, is the existence of bailment law, another field of law linked - though not only - to consignments. Bailment law comes in touch to consignment law, at least, for two reasons. First, as consignment presumes transfer of the possession on the consigned goods, bailment law comes into application related to such questions as what the obligations of the bailee are as far as the maintenance, safeguarding, ensuring and handling of the bailed goods are? Namely, although UCC Article 9 - i.e., secured transactions law - regulates how to provide public notice about the consignor's interest and how to enforce the so-created security interest, it does not regulate these other issues but leaves that function to bailment law. Secondly, as every consignment presumes bailment of goods and yet as for the purposes of secured transactions law only those consignments are of interest that entail the 'sale' of those goods, if that precondition is not fulfilled, such transactions will be nothing else but bailment subject only to that law. White and Summers names such lookalikes of conventional consignments as 'quasi consignments. ${ }^{87}$

As bailments are often created consensually and hence some authors have stressed rather the contractual facet of bailments, ${ }^{88}$ it seems that in Continental European systems its most important functional equivalents also the creatures of contract law (e.g., in German law: "Verwahrungsvertrag" ${ }^{\text {“89 }}$ - meaning deposit or custody). Perhaps of bigger importance is that while in the Continental European systems bailment rules are scattered over more branches of law and differ depending on what kind of contract is at stake, in common laws bailment law is a compact and hence more systematized. From the perspective of the DCFR it is

87 James J. White \& Robert S. Summers, Uniform Commercial Code (West, $6^{\text {th }}$ ed., 2010), at 1168 .

88 As a renowned source put it „The customary definition of a bailment considers the transaction as arising out of contract. Thus Justice Story defines a bailment as 'a delivery of a thing in trust for some special object or purpose, and upon a contract express or implied, to conform to the object or purpose of the trust [Joseph Story, Bailments $6\left(9^{\text {th }}\right.$ ed. 1878)]. There has, however, been a vigorous dissent to this insistence on the contractual element in bailments. Professor Williston ... defines bailments broadly as the rightful possession of goods by one who is not the owner' [4 Samuel Williston, Law of Contracts 2888 (rev. ed. 1936)] ... It is obvious that the restricted definition of bailment as a delivery of goods on a contract cannot stand the test of the actual cases. The broader definition of Professor Williston is preferable." Ray Andrews Brown, the Law of Personal Property $₫ 73$, at 252, 254 (2d ed., 1955). Quoted by the Black's Law Dictionary, DeLuxe $9^{\text {th }}$ Edition (2009).

89 The custody contract is regulated by $₫ 688$ of the German Civil Code (BGB), which states „Vertragstypische Pflichten bei der Verwahrung - Durch den Verwahrungsvertrag wird der Verwahrer verpflichtet, eine ihm von dem Hinterleger übergebene bewegliche Sache aufzubewahren." 
a legitimate question deserving answer whether such versions of consignments should also be excluded by the European system or rather specific policy reasons might vouch for a different solution?

A final gloss on the regulation of consignments is needed her. Contrary to general commercial consignments, the art market has idiosyncratic problems because of what many States have passed specific legislation on consignment of artworks to prevent abuses of artists by dealers ${ }^{90}$ and dealers' financiers. ${ }^{91}$ This created another layer of law affecting a specific consignment-exploiting industry. These statutes impose obligations on the dealers and foresee strict penalties for the breach of the law in addition to the fiduciary duties the agency nature of the relationship entails. Namely, at the moment artwork is delivered by an artist to a dealer, ,[u]nder common law ... the dealer becomes the artist's agent and the laws of agency govern. "92 In addition to being subject to these statutes, UCC provisions apply also to the artist-dealer relationships even though in this industry it is generally known that dealers are selling goods owned by somebody else. Critics exactly because of this criticized the sweeping changes brought about with the 1999 revision of UCC Article 9. As vividly stated by one of the critics the problem is that UCC „treats the consignment of art to the gallery the same way [it] would treat the consignment of screwdrivers to a shop." ${ }^{33}$ While some open questions remain, consignments by artists to art dealers are now excluded transactions, because of why they are figuring as a particular type of 'orphan consignments' in our Appendix below.

90 While California amended its Civil Code (ss. 1738-1738.9), other states have passed leges speciales, like New York - Arts \& Cultural Affairs Law (McKinney Supp. 1999) or Florida - Fla. Stat. Ann. Title XXXIX.

91 The disadvantages of the protection of the financiers of consignee at the account of consignors „are most easily seen in the art market, where both the culture of the art world and the commercial nature of the art market work to the detriment of the artist/consignor. Because artists rely on the honesty of art dealers and typically remain unaware of the mandates of the Code, they will lose their works of art to creditors if the dealer goes bankrupt. The plight of the artist has been recognized by a majority of state legislatures, including those of New York and California, which have enacted legislation that provides artists greater protection from a dealer's creditors than that which is provided by the Code. However, many of these statutes are poorly drafted and so fail to adequately protect the art consignor against a consignee's creditors. [...]." See Mark Marcone, the UCC and Consignment: Making the Code Safe for Artists and other 'Little Fellows' 12 Cardozo Arts \& Ent. L.J. 579 (1994).

92 Roy S. Kaufman, Art Law Handbook (Aspen Publishers, Inc., Gaithersburg, 2000), at 514.

93 From the case Asante Technologies, Inc. v. PMC, Sierra Inc., 164 F.Supp. 2d 1142 (N.D. Cal. 2001), at 1148, and quoted by Hilary Jay, A Picture Imperfect: the Rights of Art Consignor-Collectors when their Art Dealer Files for Bankruptcy, 58 Duke L.J. 1859, 1860. 


\section{Consignment and Secured Transaction Law}

\subsection{OVERVIEW OF THE REGULATION OF CONSIGNMENTS}

The hectic history of the relationship of secured transactions and consignment ought to be divided into three phases: the pre-UCC period, the regulation of consignments by the UCC until the 1999 Revised Version, and finally the solutions of this Revision itself. Apart from the very beginnings when presumably only 'true' consignments were known and when the law could have been simple, the rest of this period is full with hesitancy, among others, on whether consignments are matters for sales law or rather they are closer to secured transactions law. The division to true consignments and consignments which were in fact disguised security interests was also the product of the pre-UCC period.

Three characteristics seem to have been common to all versions of UCC. First, all versions of UCC were concerned with how to inform the public about the true position and powers of the consignee - i.e., what form of public notice to utilize against ostensible ownership. Under the pre-1999 version that was achieved through a system based on a formula combining 'sign law-cum-Article 9 filing.' The Revised Version's radical move was removal of all consignments from the realms of UCC Article 2 on sales, what however should not be understood that now all types of consignments are caught by Article 9 (i.e., there are explicit exclusions). Yet all consignments caught by secured transactions law are subject to Article 9's perfection (public notice-providing) requirements. The second common feature is that no simple and easily applicable formula for the treatment of consignments has been arrived at so far. This applies also to the latest one in the Revised Version, which contains a definition that is both, hard to understand and to apply. In sum, albeit the new set of rules „clarifies a number of minor points that arose under prior law [but it] also creates some new areas of uncertainty. "94

The third commonality was the result of the previous two and it concerned the practical advice how to deal with the inherent uncertainties. The recipe for the maladies, originally put forward by the father of UCC Article 9, Grant Gilmore, was that consignors should 'In case of doubt, file?. As recommended by leading authors: "the clear message of the drafters of the U.C.C. was to all consignors [was] that, at a minimum, filing of a

94 G. Ray Warner, Consigned to Confusion: Consignments under Revised Article 9 20JAN Am. Bankr. Inst. J. 30. 
financing statement is necessary in order to protect the consignor's interest in the consigned goods. "95

Talking of the pre-UCC period, on the federal level the US Supreme Court's holding in Ludvigh v. American Wollen $\mathrm{Co}^{96}$ was the ruling of the day. ${ }^{97}$ According to this consignments ,fairly entered into and carried out" were enforceable even against trustee in bankruptcy of the consignee. ${ }^{98}$ Yet the lower courts have not embraced this position and have rather looked upon consignments as disguised secured transactions creating secret liens potentially misleading the other creditors of the consignee. As a result of this dichotomy, eventually the category of 'true consignments' got distinguished from disguised secured transactions. While true consignments were protected by the Supreme Court ruling, the others were not. Since those days, one of the tasks of US courts was to design factors for differentiation between the two. Notwithstanding the criticisms and the awareness, this problem has not been satisfactorily resolved even by the 1999 Revised Version given that no definition of what 'securing an obligation ${ }^{29}$ - crucial element for identifying disguised security interests - was formulated.

The drafters of the pre-1999 versions of UCC were still hesitating whether to deal with consignment-related problems through sales or se-

95 Richard F. Duncan, William H. Lyons and Catherine Lee Wilson, the Law and Practice of Secured Transactions: Working with Article 9 (Law Journal Press, New York, version of 2011), $\$ 1.04(3)(b)$.

96231 U.S. 522, 34 S.Ct. 161, 58 L.Ed.345 (1913).

97 As described by Gilmore, „[c]onsignment was never thought of as a security device [given that] there is no obligation to be secured. [As a result] it was not usually subjected to filing statutes, although a few statutes required that signs be posted on the consignee's business premises to give notice of the consignor's interest. Under such statutes or as a matter of common law the consignor was protected against the consignee's creditors and on insolvency was entitled to reclaim the goods from the consignee's trustee in bankruptcy." See Grant Gilmore, Security Interests in Personal Property (Little, Brown and Co., 1965), at 74.

However, similarly to the other $19^{\text {th }}$ century independent security devices using personal property (i.e., movables and intangibles), consignment was also changed into a security device by appropriate contract drafting. "This was usually done by drafting, exclusively in consignment language, an agreement under which the 'consignee' was under a duty to pay for the goods 'consigned' whether he sold them or not." Id, at 75.

98 Richard F. Duncan, William H. Lyons and Catherine Lee Wilson, the Law and Practice of Secured Transactions: Working with Article 9 (Law Journal Press, New York, version of 2011), $\$ 1.04(3)(b)$.

99 In White and Summer's example, „[i]f ... a debtor borrowed money from a creditor, granted a security interest in inventory and promised to repay the sum whether or not the goods were sold, that transaction would be treated in all respects like a secured transaction even if the parties labeled it a 'consignment' [...]." James J. White \& Robert S. Summers, Uniform Commercial Code (West, $6^{\text {th }}$ ed., 2010), at 1166. 
cured transactions law. The main source of confusion thus came to be exactly regulation by both. The 1999 revision has resolved at least this problem through the seemingly Solomonic solution of having "moved almost all commercial consignments into Article 9-at least for most purposes" 100 the primary effect of what was their treatment "like purchase-money security interests in inventory. " 101 The purchase-money status gives super-priority to the consignor if complying with the perfection provisions of Article 9. ${ }^{102}$ This was based on the realization that filing under Article 9 was not only safe, sure and inexpensive but also a method for protection of consignors without the "risk of jeopardizing a true consignment by turning it into a secured transaction." "103 As a result, US sources agree that the 1999 revisions of Article 9 on consignments (and the conforming amendments to section 2-326) were, even if not simple and complete yet significant improvements, though "[t]he law [remained] at least as complicated as before but, at least for the diligent, more certain". 104

As a consequence of the changes, present time UCC Article 9 catches three types of consignments: conventional (or non-obvious) consignments, disguised - or consignments securing and obligation - and consignments with processing and subsequent sale. The first differs from true (or obvious) consignment because to clients of such consignees nothing reveals the true nature of the transactions. To wit, the consignee acts in his own name when selling the goods of consignor secured by his retained title or is not known by the wider public to be 'substantially engaged in selling the goods of others.' Such conventional commercial consignment is a secured transaction and the consignor's interest qualifies as a security interest. Moreover, by explicit language of the Code, such consignment creates a purchase money security interest. In this case the consignor, however, is not subject to the restrictions Article 9 imposes on foreclosure (restrictions on repossession and disposition of collateral) and "[t]he consignor may get its goods back by whatever method is permitted under the state law outside of Article 9." 105

100 Id., at 1166.

101 Ray Warner, Consigned to Confusion: Consignments under Revised Article 9, 20JAN American Bankruptcy Institute Journal 30 (2002).

102 Consignor - if complying with the perfection rules of Article 9 - will have priority over bankruptcy trustee, lien creditors and non-ordinary course buyers and lessees. His security interest (retained title) in the consigned inventory will be subordinate to the rights of ordinary course buyers and lessees even if he files. Id., at 40.

103 See William D. Hawkland, Hawkland Uniform Commercial Code Series, Revised Article 9. Secured Transactions - Title Retention Contracts, Leases and Consignments (2001) [no publication page references were available for the document].

104 James J. White \& Robert S. Summers, Uniform Commercial Code (West, $6^{\text {th }}$ ed., 2010), at 1168 .

105 James J. White \& Robert S. Summers, Uniform Commercial Code (West, $6^{\text {th }}$ ed., 2010), at 1167 . 
The second category subject to UCC Article 9, the consignment securing an obligation, is subject to all the rules of UCC Article 9 (i.e., filing); including the restrictions imposed on enforcement. This is so as this type of consignment is intended to create a genuine security interest.

The third category - conveniently named here as 'extended' or 'processing-cum-sale' consignment is a derivative of conventional ones. Here the crucial requirement is again dependent on who sells the goods, even though processed or even commingled with other goods first. The rule is that if "the goods are to be processed and then sold by the processor [himself] to persons to be selected by him "106 the transaction will qualify as consignment and hence the consignor will fend off adverse claims against such goods by filing.

Besides the consignments caught by the system, three classes of transactions, to wit 'obvious ${ }^{107}$ consignments, one form of quasi-consignments and the so-called 'orphan consignments" have been left to state law and pre-1999 precedents. ${ }^{108}$ In the case of the first category, as the consignee is visibly either acting in the name of the consignor or is known by others to be engaged in "substantially selling the goods of others" - and that is easily determinable by the other participants of the market - the protective hands of secured transactions law are not needed. Here, imposition of the requirement of filing would in fact would only double unnecessarily the transaction costs. In case of two other excluded classes, the unacceptable cost-benefit ratio and the need for heightened protection of consumer consignors were the reasons for behind the exclusion of consignment of goods of value less than $\$ 1,000$ and of consumer goods. ${ }^{109}$ These consignments now again subject to Article 2 and sales "the rights of the creditors

106 See James J. White \& Robert S. Summers, Uniform Commercial Code (West, $6^{\text {th }}$ ed., 2010), at 1169 also quoting point 14 of the Official Comment to section 9-102 which reads: "The definition of 'consignment' requires that the goods be delivered 'to a merchant for the purpose of sale.' If the goods are delivered for another purpose as well, such as milling or processing, the transaction is a consignment nonetheless because a purpose of the delivery is 'sale'. On the other hand, if a merchant-processor-bailee will not be selling the goods itself but will be delivering to buyers to which the owner-bailor agreed to sell the goods, the transaction would not be a consignment. ",

107 Note that the attribute 'obvious' is a designation used, neither by UCC Article 9, nor by US scholars. Yet in the opinion of the author it is useful to distinguish it from other equally non-standardized words.

108 See the Appendix. As point 14 of the Official Comment to Section 9-102 of the Revised Version explains their exclusion because these are "transactions for which filing would be inappropriate or of insufficient benefit to justify the costs."

109 See, e.g., George H. Singer \& Michael P. Warren, The ABCs of the new UCC: How to Consign under Revised Article 9 62-MAR Bench \& B. Minn. 28 (March, 2005), at 30 stating that "These two restrictions remove from the scope of Article 9 smaller consignments, such as the delivery on consignment of clothes or sporting goods to a thrift 
of the consignee of this ... type will have to be determined by looking at the common law of the particular states [and the] lawyer will have to pick and choose among the old cases based on the language of the two versions of [UCC section] 2-326 and on the issue in the case." 110

Sales law governs yet another brother of consignments now: the 'saleor-return' 111 transactions. Although having shared a common history in the pre-1999 period, these should not to be listed anymore next to consignments because they are conceptually different: „a sale-or-return transaction is a present sale and the recipient of the goods is a 'buyer,' whereas there is neither a present sale nor a buyer in a true consignment. It is this technical conceptual distinction that caused the drafters [of the Revised Version] to decide that consignments should be removed from Article 2-because Article 2 should deal only with the 'sale' of goods." 112 In other words, 'saleor-return' is a present sale of goods which may be undone at the buyer's option. ${ }^{113}$

While the exclusion of these transactions might have been justified for the drafters of the Revised Version, the same logic might not be fully applicable in other jurisdictions - especially in systems which had very limited experiences with consignments. The radically different economy, the differing industries being present in the financial world and the many other idiosyncratic feature of Europe require a fresh look at consignmentrelated dilemmas - in particular exclusions.

\subsection{THE US CONSIGNMENT MATRIX}

Europeans searching for the formula on what transactions should be made subject to the new system, the analysis of UCC's treatment of consignments is the place to depart from. This query has two aspects, out of which only the first can be easily answered: in order to prevent bypassing

store. The rights of consignors and creditors in the consignee in such transactions are governed by applicable bailor/bailee law."

110 Id., 1167-68.

111 See UCC Section 2-326. Another variation of sales contracts - 'sale on approval' (or 'on trial' had a similarly clause relationship with consignments in the past but now is only regulated by sales law, concretely UCC Section $2-326$. Here, the goods are „delivered to the proposed purchaser but they remain property of the seller until the buyer accepts them. [...]. [Subsection 2 of Section 2-326] provides that the goods delivered on approval are not subject to the prospective buyer's credits until acceptance."

112 G. Ray Warner, Consigned to Confusion: Consignments under Revised Article 920 JAN American Bankruptcy Inst. Journal 30 (2002).

113 Point 1 of the Official Comment to UCC Section 2-326.Under 'sale or return' the goods are "are subject to the buyer's creditors while in the buyer's possession." Id. 
of the intended new rules not only those transactions should be caught by the system that are named exactly as 'consignment'. A more prescriptive language should guide courts and businesses to achieve that end - what is not the case at the moment with the DCFR. It is perhaps of help that in Europe consignments are typically linked to other nominated contracts (typically forms of trade representation and agency) hence looking 'behind the contractual façade' is often a must anyhow. ${ }^{114}$

The less easily answerable question is how many classes of „consignments" (named that way or not) are there and which of them should become subject to the secured transactions system and which should be left to other branches of law? These puzzles obviously require also identification of the policy questions that should lead the legislators and courts in finding the right responses. The matrix of 'consignments' as per US law - sketched in the Appendix below - might exactly in that process be of interest. $^{115}$

This is so as each of the identified forms of consignments and quasiconsignments present different types of problems of varying complexity and were the basis for specific rules now enshrined into UCC Article 9, their analysis in isolation would be misleading and would not explain the main justification for the transformation of consignment to the secured transactions system. Europeans should therefore as well specifically pronounce what should happen to each of these forms, along with the concomitant dilemmas.

\section{In LiEu of Conclusions}

Even based on this brief synopsis of US law, a number of questions lends to be formulated on consignments and their subjection to secured transactions law - each deserving the attention of Europeans pondering what to do with the put forward idea of exploiting consignments more extensively for financing, especially of SMEs. Needles to say, first, a proper definition of consignment should be found; including the illumination of

114 The drafters of UCC Article 9 introduced such a functional thinking vis-à-vis all secured transactions (not just consignment) by the following formulation: „Under this Article the traditional distinctions among security devices, based largely on form, are not retained; the Article applies to all transactions intended to create security interests in personal property and fixtures, and the single term 'security interest' substitutes for the variety of descriptive terms which had grown up at common law and under a hundred-year accretion of statutes. This does not mean that the old forms may not be used." See Official Comment to UCC Article 9 section 9-101 pre-Revised Version.

115 See the Appendix below. 
even such concepts as 'when does a consignment secure an obligation' what is still not fully clear in the US. To get to the properly delineated definition, however, such basic policy questions must be answered like exactly which types of consignment (and quasi-consignment) transactions need to be converted into security interests? This is partially linked to the systemic question of how to apportion the pertaining tasks between sales and secured transactions law? The decades lasting US struggle with finding the proper border should be instructive in that respect. Last but not least, it is a linked issue whether the civilian systems' compartmentalized functional equivalent rules of Anglo-Saxon compact bailment laws can properly resolve the problems corollary to what we named as 'orphan quasiconsignments'? ${ }^{16}$

Secondly, it is likewise far from being irrelevant which consignments should be excluded by the system. For one thing, if 'obvious' consignments ${ }^{117}$ should have a life of their own - as it is now after the 1999 revision of the UCC - then it should be determined in case of which transactions can it be presumed that their true nature is obvious beyond any doubt? UCC's choice to leave the filing option open to this class of consignors - without risking that such filing will be taken as proof of the existence of a disguised security interest - was obviously a way to resolve this particular concern. Commentators, indeed, recommend sticking to the precautionary filing of financing statements also under the new system ${ }^{118}$ as due to the surviving uncertainties courts may still find that a transaction labeled as 'consignment' was in fact a disguised security interest $^{119}$ - affecting the position of the consignor. Neither the dilemma, nor the scrutiny of the US answer to it should be bypassed as not just the business practices but even the perception of consignment seems to be different in various niches of Europe.

116 These are identified in the Appendix as 'quasi-consignments type one' (A3), which are in US subject to bailment law.

117 This would be category A1 in the Appendix.

118 See, e.g., Warren and Walt, Secured Transactions in Personal Property (Foundation Press, 2007), at 360 - stating that „[p]rudent commercial consignors have been filing financing statements since the 1962 Code was enacted, and they will continue to do so under Revised Article 9." [Emphasis added.]

119 In the case of Mann v. Clark Oil \& Refining Corp., 302 F. Supp. 1376 (E.D.Mo. 1969) the court found a security interest even though as per the arrangement of the oil company and the gasoline dealer, the latter was obliged to return the gasoline if it failed to sell the consigned gas. Under the Revised Version, this transaction would not be covered by Article 9 but rather by sales law as it was in fact on a 'sale or return'. The case In RE Gross Mfg. \& Importing Co., Inc., 328 F. Supp. 905 (D.N.J. 1971) is even more instructing because here the court found a security interest „even though there was no obligation to pay for the goods in any event." Id. 
Thirdly, the US definition of consignment - based on presumptions on what creditors think about variously positioned consignees - are obviously based on American realities; what certainly is different in Europe. In fact, these postulates were criticized for similar reasons even in the US: i.e., for foreseeing the same rules to all industries exploiting consignments. ${ }^{120}$ While admittedly the Revised Version's complex definition seem to have entertained some industries' expectations, empirical studies should be conducted to more properly define the contours, business practices and expectations of the potentially affected European industries. Behavioral economists should perhaps be involved in the process.

Fourthly, differences in bankruptcy philosophies on the two continents should also matter given that the conflict of consignors and consignee financiers typically occur upon the bankruptcy of the consignee. Until that point in time, the consignor's retained title and the inventory financier's security interest can peacefully coexist (presuming that no other liens interfere). Given that in Europe the number of business bankruptcies is still significantly lower compared to the US, which might be a fact to reckon with.

Finally, and most importantly, the complexity of the topic should not scare off anybody from at least decently discussing what consignment's subjection to a secured transaction regime would mean. No other panacea exists against the reform-phobia but the hoped for increased access to financing; especially but not exclusively by SMEs. If it can be accepted that secured transactions law - as demonstrated by the most developed and hence also the most tested systems - can contribute to growth through increased access to financing, then the daring innovation of the DCFR should be welcome, even though it seems hardly have all consignmentrelated questions been fully explored and answered by its drafters. The choice between venerable principles and reforms should be made based on these considerations and the fact that in the US these laws are as a rule not exploited by amateurs but rather by highly professional industries. European businesses and financiers potentially profiting from the novelties, therefore, must have also a determinative say on that matter.

Answering the ultimate question in a more complete manner of whether the DCFR has properly addressed all the queries raised by this paper and what else may have come to mind pondering the pros and cons of the new solution - is left to the reader and to the scholars who will decide to deal with the topic.

120 See, e.g., Mark Marcone, the UCC and Consignment: Making the Code Safe for Artists and other 'Little Fellows' 12 Cardozo Arts \& Ent. L.J. 579 (1994). 


\begin{tabular}{|c|c|c|c|c|}
\hline \multirow{3}{*}{ 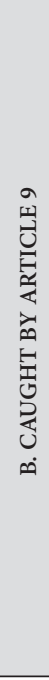 } & 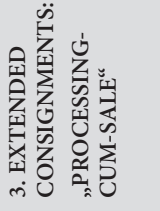 & \multicolumn{2}{|c|}{ 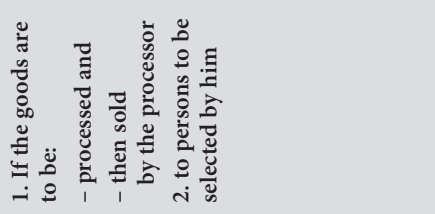 } & 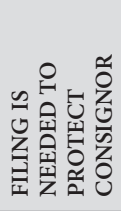 \\
\hline & 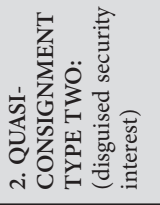 & \multicolumn{2}{|c|}{ 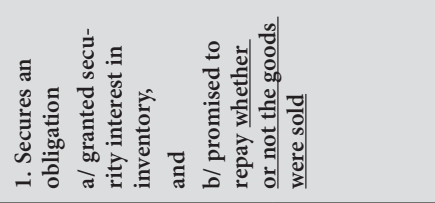 } & 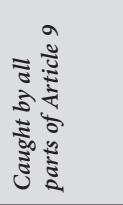 \\
\hline & 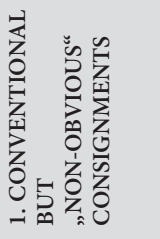 & 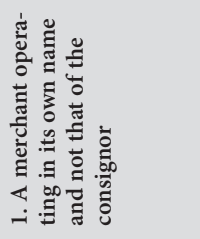 & 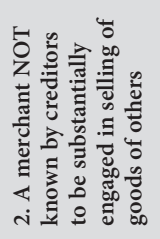 & 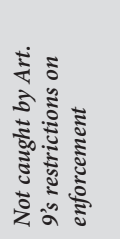 \\
\hline \multirow{3}{*}{ 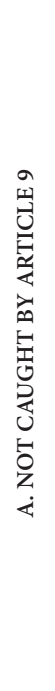 } & 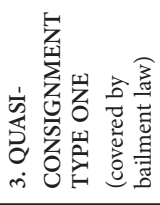 & 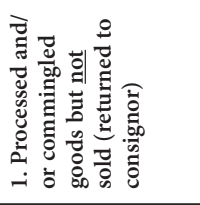 & 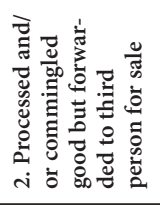 & 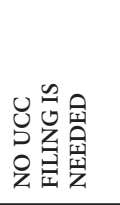 \\
\hline & 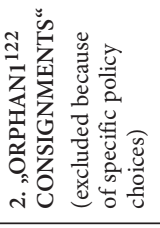 & 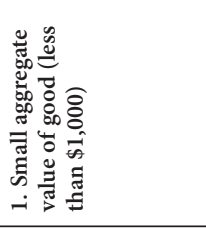 & \multicolumn{2}{|c|}{ 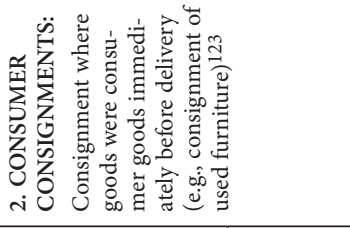 } \\
\hline & 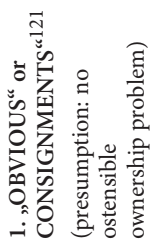 & 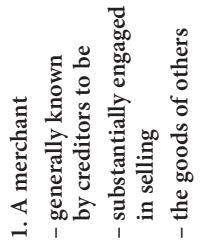 & 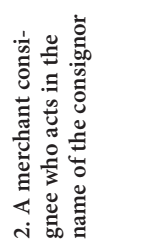 & 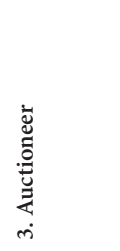 \\
\hline
\end{tabular}

121 While the attribute 'obvious' is the invention of the author of this paper, the designation of 'true' was the product of US courts. Yet from a comparative perspective the 'obvious' better explains the essence than 'true' - for example when comparing the above $\mathrm{A} 1$ and $\mathrm{B} 1$ categories.

122 The apt expression seems to have been invented by Ray G. Warner in his article Consigned to Confusion: Consignments under Revised Article 9 20-JAN Am. Bankr. Inst. J. 30 (2002).

123 See James J. White \& Robert S. Summers, Uniform Commercial Code (West, $6^{\text {th }}$ ed., 2010), at 1166 - stating: „Certain transactions a layperson would describe as consign- 


\title{
KONSIGNACIJA I NACRT ZAJEDNIČKOG REFERENTNOG OKVIRA ZA EVROPSKO PRIVATNO PRAVO
}

\author{
Tibor Thaythy
}

\section{REZIME}

Oblast koja je sigurno najbogatija novinama za evropske pravnike u trenutno najznačajnijem dokumentu što se evropskih napora ka harmonizaciji prava tiče, tzv. Nacrtu zajedničkog referentnog okvira za evropsko privatno pravo (Draft Common Frame of Reference), jeste IX knjiga o založnom pravu na pokretnim stvarima i pravima. To se u velikom delu može pripisati uticaju američkog modela kodifikovanog u devetom poglavlju (inače za evropske standarde nelogično nazvanog Član 9 - Article 9) Jednoobraznog trgovačkog zakonika (UCC). To je onaj model koji je inspirisao ne samo anglosaksonske pravne sisteme, počev od kanadske provincije Ontario krajem šezdesetih godina pa do Australije, gde je baš ove godine stupio na snagu novi zakon sa sistemom po uzoru na američki, nego i najveći deo reformski orijentisanih istočnoevropskih zemalja. Danas skoro da nema postsocijalističke zemlje u Evropi koja se nije bar jednom latila reformi založnog prava radi poboljšanja uslova kreditiranja. Ovaj članak je posvećen baš jednoj od takvih, doduše u Evropi još neiskorišćenih novina, to jest načinu i razlozima podvođenja konsignacijskih ugovora pod novi založnopravni režim.

Najvažnija karakteristika devetog poglavlja Jednoobraznog trgovačkog zakonika (UCC) jeste tzv. funkcionalan pristup pravu. Odnosno, podvođenje svih transakcija koje služe kao sredstva obezbeđenja kredita pod založnopravni režim, bez obzira na njihov naziv - pri tom pod 'kreditom' podrazumevajući ne samo zajam (loan-credit) nego i privilegiju da se cena ne plati odmah po prijemu robe (sale-credit). Tako, protivno shvatanju kontinentalno evropske pravne dogmatike, lizing pa i konsignacija smatraju se založnim ugovorima. Novi tretman konsignacije prema Nacrtu zajedničkog referentnog okvira u osnovi se svodi na to. Doduše ni iz teksta Nacrta, niti iz dosadašnjih komentara ne vidi se tačno koliko duboko će novine ići. Na primer, prema američkom sistemu, konsignantovo svojinsko pravo nad stvarima datim u konsignaciju i u rukama konsignatara mora da se registruje u jednom javnom registru, kao i da važe posebni prioritetni principi i pravila naplate. Odnosno, konsignantova pridržana svojina neće biti puna svojina, samo stvarno pravo jednako založnom pravu i bez obzira na njegovu zadržanu svojinu, drugi finansijer će moći da ima prioritet u naplati.

ments are not consignments as that term is used by Article 9. Thus, a consignment of used clothing and used furniture to a consignment store is not a „consignment.“ 
Ovaj američki sistem je proizvod tri faktora. Kao prvo, bojazan od prividnog vlasništva (ostensible ownership ili false wealth), što postoji u slučaju svih takvih ugovora gde se založni objekat predaje u državinu dužnika za vreme trajanja ugovora. Državina se pak može tumačiti od strane ostalih učesnika prometa kao vlasništvo, na osnovu čega dužnik može ne samo otuđiti tu stvar, nego je može i založiti za dobijanje kredita. To je ona nit koja vezuje, na primer, hipoteku, lizing i konsignaciju, bar po američkom pravu. Već se i englesko pravo razlikuje od ovog pristupa, jer po njemu ugovori koji se zasnivaju na pridržaju svojine ne mogu biti ravnopravni sa založnim pravom jer se založno pravo ne može osnovati zadržavanjem (retention versus grant) stvarnoga prava. Nemačko pravo je još $\mathrm{u}$ XIX veku rešilo ovaj problem uvođenjem radikalnog principa zabrane kreiranja novih stvarnih prava (numerus clausus), pa i sredstava obezbeđenja sa stvarnopravnim dejstvima. To je razlog da i dan-danas nemački privatni i trgovački zakonici poznaju jedino ručnu zalogu kao formu založnog prava nad pokretnim stvarima (zadržanje svojine nad stvarima je isto regulisano ali se ne poima kao forma založnoga prava). Za razliku od toga, anglosaksonski pravni sistemi su zauzeli jednu liberalnu poziciju prema kojoj, s jedne strane, nemaju zabrane kao nemački, ali, s druge strane, nova sredstva obezbeđenja biće punopravno priznata samo ako ostali učesnici prometa budu o tome obavešteni, prvenstveno putem registracije u za to otvorenoj javnoj knjizi. Kako je kapitalizam već u XIX veku stvorio veći broj posebnih sredstava obezbeđenja (npr. hipoteka na pokretnim stvarima, lizing, lebdeća zaloga), stvoren je i veći broj javnih registara, često sa nejasnim pravilima. Član 9. Jednoobraznog trgovačkog zakona postigao je toliki uspeh baš zbog toga što je sva ta posebna sredstva podveo pod jedan jedinstveni sistem, uključujući i centralizaciju registracije na nivou pojedinih saveznih država.

Drugi faktor od uticaja je bilo to da su neka od ovih sredstava obezbeđenja bila zamišljena i korišćena radi izbegavanja prethodno već uspostavljenih registara i pravila. Na primer, u istočnoj Evropi sada popularan lizing (bez obzira da li finansijski ili operacioni) izrastao je iz težnje da se izbegnu obaveze registracije većeg broja ugovora (tada još pisanih rukom), suviše formalnih pravila o načinu naplate iz založnog objekta propisanih za tzv. hipoteku na pokretnim stvarima (chattel mortgage), kao i svi rizici vezani za njihovu veoma formalnu proceduru kreiranja. Danas lizing nije isto što i pomenuta hipoteka ili konsignacija, doduše u sva tri slučaja glavno sredstvo obezbeđenja jeste zadržana ili preneta svojina - odnosno manipulisanje svojinom na založnoj stvari.

Treći faktor je pravnopolitička odluka (policy choice) da se preko založnog prava stvore uslovi za dobijanje, ako treba, i više kredita i od većeg broja finansijera. To se postiglo, s jedne strane, tako što skoro svaka stvar 
koja se može prodati na tržištu sada može da služi kao predmet zaloge. S druge strane, preko posebnih prioritetnih i notifikacionih pravila, omogućilo se i to da ista stvar bude predmet više zaloga, pa da se tako omogući pristup kreditima od više finansijera. Danas, u vreme svetske finansijske krize ove solucije će se činiti suludim, ali ne treba zaboraviti da je i dan-danas finansiranje najvažnijeg segmenta ekonomije čak i najrazvijenijih zemalja - finansiranje malih i srednjih preduzeća koja zapošljavaju najveći broj stanovnika - ostalo nerešeno. Na primer, mogućnost dobijanja jednog kredita na osnovu lebdeće zaloge koja pokriva svu sadašnju i buduću imovinu jednog preduzeća najverovatnije neće biti dovoljna, te će, po pravilu, biti potreban drugi kredit po osnovu nekog drugog sredstva obezbeđenja. Bez posebnih pravila nalik na ona koje američko založno pravo zna i onih o kojima ova analiza o konsignaciji govori, teško da će se naći takvi finansijeri.

Sumirajući, shvatanje toga zašto pomenuta novina Nacrta i transformacija konsignacije u založno pravo može da ima smisla, pretpostavlja znatno više od puke komparacije. Kao prvo, bez stavljanja na stranu pravne dogmatike kontinentalno-evropskog pravnog razmišljanja i njegove zamene sa funkcionalnim poimanjem prava, teško da se može doći do srži problematike. Kao drugo, treba imati na umu da je i u Americi do ovih konceptualnih promena došlo iz veoma konkretnih ekonomskih i finansijskih razloga: kako omogućiti preduzećima da dođu do kredita neophodnih za poslovanje? To je taj konkretan ekonomski razlog zbog kojeg ima smisla staviti pod znak pitanja valjanost ustaljenih pravno-dogmatskih klasifikacija i principa i u Evropi. Takvo poimanje konsignacije u stvari znači njenu metamorfozu u sredstvo obezbeđenja kredita i posebnog oblika finansiranja naročito malih i srednjih preduzeća. Ako ne budemo imali u vidu šta u privrednom životu ova novina Nacrta zajedničkog referentnog okvira može da donese, sve će ostati ignorisano kao nepotrebna komplikacija prava.

Kako je komparativnopravna obrada teme konsignacijskih ugovora oskudna, a ekonomski potencijal skriven u konsignacijskim ugovorima kao sredstvima finansiranja ostao nezapažen i neiskorišćen u istočnoevropskim zemljama i zemljama u razvoju, ovaj članak je pokušaj da počne da se ispunjava ta praznina. Ekonomski uslovi i trgovački običaji nisu isti u Sjedinjenim Američkim Državama i u Evropi, stoga je naivno misliti da se američko pravo može jednostavno transplantirati na stari kontinent i da će se konsignacija kao način finansiranja jednostavno odomaćiti ovde. Doduše, slično kao u Americi, i u Evropi bi to prvenstveno trebalo da zavisi od potencijalnih finansijera i korisnika kredita. Kako i Evropa sada već misli da ima smisla napraviti ovaj korak, ima smisla i početi da se bavimo ovom temom. 